\title{
A High Seas Requirement for Inciters and Intentional Facilitators of Piracy \\ Jure Gentium and Its (Lack of) Implications for Impunity
}

\author{
JONATHAN BELLISH*
}

\section{TABLE OF CONTENTS}

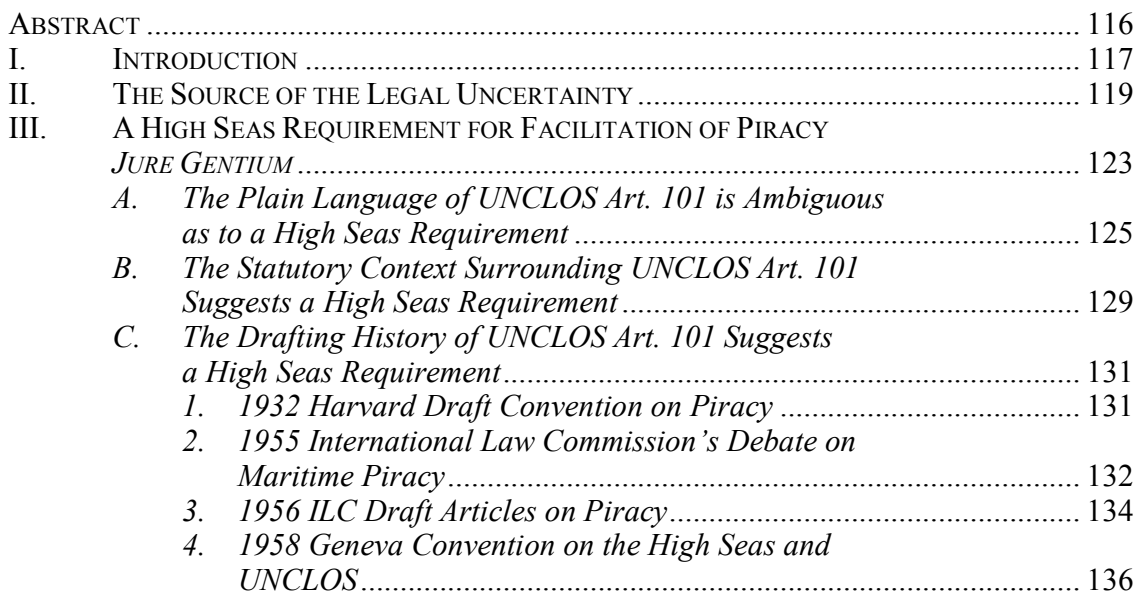

* C 2013 Jonathan Bellish. Jonathan Bellish is a Project Officer at the One Earth Future Foundation in Denver, Colorado and a Fellow at the Nanda Center for International and Comparative Law at the University of Denver Sturm College of Law. He would like to thank Ved Nanda, Yvonne Dutton, Eamon Aloyo, and Stian Øby Johansen for their helpful comments and suggestions. Any errors contained in this paper belong to the author. 
D. The Possible Policy Rationales Behind Universal

Jurisdiction Over Piracy Suggest a High Seas

Requirement

1. Inherent Heinousness-Against a High Seas

Requirement.

2. Protecting the Freedom of Navigation-Against a

High Seas Requirement.

3. Regulatory Capture - In Favor of a High Seas Requirement

4. Evidentiary Shortcut - In Favor of a High Seas Requirement...

5. Difficulty of Enforcement-In Favor of a High

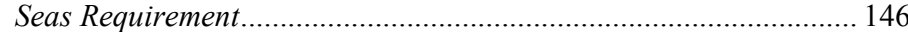

6. Lack of Implications on Sovereignty -In Favor of a High Seas Requirement.

IV. The Practical Impact of the High Seas ReQuirement

ON FACILITATORS

A. In Theory, Universal Jurisdiction Piracy Prosecutions

Should be Exceedingly Rare

1. Universal Jurisdiction Prosecutions as a Commons Problem

2. Universal Jurisdiction Prosecutions as a Public Goods Problem

B. State Practice Shows Universal Jurisdiction Piracy

Prosecutions Are Rare

1. Universal Jurisdiction Piracy Prosecutions Are a

Minority Outcome.

2. Maritime Piracy is Prosecuted at a Lower Rate than Other Crimes

\section{ABSTRACT}

Around 2005, maritime piracy made a troubling resurgence three quarters of a century after a consensus had been reached that the age of piracy had permanently ended. Yet piracy returned in a slightly different form, with pirates relying more on land-based facilitators than their historical counterparts. Maritime piracy's reappearance made ripe for consideration the question of whether a facilitator of maritime piracy must be physically present on the high seas while facilitating in order to be subject to universal jurisdiction. This Article undertakes an analysis of the text, statutory context, history, and policy impetus behind UNCLOS art. 101 as it relates to universal jurisdiction over facilitators. It finds that the weight of the evidence suggests that a high seas requirement in fact exists for facilitators of piracy jure gentium. From there, the article considers the likely implications of such a requirement on modern facilitators of maritime piracy. Through the lens of political economy, 
the Article asserts that universal jurisdiction piracy prosecutions pose something of a commons problem, or, alternatively, a public goods problem. Because rational actors operating in a market tend to internalize externalities and under-produce public goods, this theory suggests that universal jurisdiction prosecutions should be quite rare, and state practice confirms that hypothesis. In short, this article argues that there is a high seas requirement for inciters and intentional facilitators of piracy jure gentium, but the existence of this requirement is unlikely to affect the impunity of facilitators.

Can it be believed that the legislature intended to punish with death the subject of a foreign prince, who, within the dominions of that prince, should advise a person, about to sail in the ship of his sovereign, to commit murder or robbery?

\section{- Chief Justice John Marshall, United States Supreme Court ${ }^{1}$}

\section{INTRODUCTION}

Chief Justice Marshall posed the above question regarding a 1790 statute which punished accessories before and after the fact to acts of maritime piracy in the 1818 case United States v. Palmer. ${ }^{2}$ Although the Chief Justice intended the question as a hypothetical that should be answered in the negative, it remained just that-a hypothetical-for almost two centuries.

Then, in 2011, United States law enforcement officials arrested Ali Mohamed Ali when his plane landed at Dulles International Airport. ${ }^{3}$ Ali, who was serving as Director General of the Ministry of Education in Somaliland, was en route to an educational conference in North Carolina. He was charged with inter alia, piracy under the law of nations. ${ }^{4}$ A Somali citizen, Ali was charged with negotiating on behalf of other Somalis who captured a Bahamian-flagged, Danish-owned ship and held its Russian, Georgian, and Estonian crew hostage for sixty-nine days. ${ }^{5}$ His prosecution in the U.S. is therefore predicated purely on the theory

\footnotetext{
1. United States v. Palmer, 16 U.S. 610, 633 (1818).

2. Punishment of Crimes Act of 1790, ch. 9, §§ 10-11, 1 Stat. 112, 114.

3. United States v. Ali, 885 F. Supp. 2d 17, 21 (D.D.C. 2012).

4. Id.

5. Id.
} 
of universal jurisdiction ${ }^{6}$ since the government stipulated that Ali did not intentionally facilitate piracy while physically present on the high seas. ${ }^{7}$ Around the same time, a federal grand jury charged Mohammad Saali Shibin for his role as a negotiator in the hijacking of the MV Marida Marguerite, a German-owned Marshall Islands flagged vessel with a crew of nineteen Indians, two Bangladeshis, and one Ukrainian. ${ }^{8}$ Like Ali, Shibin did not board the ship until it was "just off the coast of Somalia," so the United States' case against him for his actions aboard the Marida Marguerite rests solely on the theory of universal jurisdiction.

Thus Ali and Shibin, the subjects of a foreign "prince" and "within the dominion of that prince," both advised persons who had just sailed the high seas how to successfully complete the robbery. They thereby transformed Chief Justice Marshall's question from hypothetical into reality. After 200 years, the question of whether universal jurisdiction exists for facilitators of piracy who do not facilitate from the high seas or any other place outside the jurisdiction of a state is finally ripe for serious consideration.

The ripeness of the question of a high seas requirement for facilitators of piracy goes beyond the purely legal. It speaks directly to the manner in which the international community goes about bringing an end to the scourge of piracy on the high seas. The geography of Somalia, combined with a lack of economic opportunities in the state, has led to a situation with no shortage of Somali men and boys willing to risk their lives as pirates. Prosecuting individuals higher up on the criminal conspiracy chain, those who invariably operate from within the territory of a single state, is seen as a more effective method of achieving deterrence through criminal justice than low-level prosecutions alone. ${ }^{9}$ Thus whether there

6. See Eugene Volokh, From Prof. Eugene Kontorovich, About Today's Piracy Decision, The Volokh ConsPiracy (July 13, 2012, 5:50 PM), http://www.volokh. com/2012/07/13/from-prof-eugene-kontorovich-about-todays-piracy-decision/.

7. Martha Neil, Federal Judge Blasts US Prosecutors for "Unbelievably Inexcusable Behavior" in Somali Piracy Case, A.B.A J. (July 23, 2012, 5:15 PM), http://www. abajournal.com/news/article/federal_judge_blasts_prosecution_in_somali_piracy_case_for unbelievably ine/.

8. United States v. Shibin, No. 2:11CR33, 2012 WL 8231152, at *1-2 (E.D. Va. Apr. 16, 2012). Also note Shibin was charged for his role in the hijacking of the Quest in which four United States citizens were killed. $I d$. at *1. Because the United States has jurisdiction over Shibin under the passive personality theory of jurisdiction, Shibin's role in the Quest raises separate legal questions from the ones addressed here.

9. See Andrew Shapiro, Assistant Sec'y, Bureau of Political-Military Affairs, Remarks to International Institute for Strategic Studies: U.S. Approaches to CounterPiracy (Mar. 30, 2011), available at http://www.state.gov/t/pm/rls/rm/159419.htm ("Furthermore, [the U.S. Department of State is] looking at additional ways to more aggressively target those who organize, lead, and profit from piracy operations, including 
is a high seas requirement for land-based facilitators has a direct bearing on the optimal strategy for gathering evidence against and prosecuting those most responsible for the resurgence of piracy off the Horn of Africa. This paper seeks to address both the legal question of whether a high seas requirement exists and the practical results that flow from the disposition of that question. It argues that there is indeed a high seas requirement for facilitators of piracy jure gentium under customary international law as reflected in the United Nations Convention on the Law of the Sea (UNCLOS), but such a requirement is not likely to result in impunity for inciters and intentional facilitators of piracy who operate solely from dry land.

Part II of this article characterizes the uncertainty around a high seas requirement for pirate facilitators, providing some historical context to the legal debate. Part III considers whether there is a high seas requirement for facilitators of piracy jure gentium.It concludes that, while the question is ultimately one that will be answered by state practice, there is strong evidence suggesting that UNCLOS and customary international law place a high seas requirement on pirate facilitators. In considering this question, Part III evaluates the text of UNCLOS art. 101, its context, drafting history, and several plausible policy reasons for piracy's status as the original - and for centuries the sole - universal jurisdiction offense. Part IV shifts focus from whether there is a high seas requirement to what the implications of such a requirement might be. Political economic theory predicts very few universal jurisdiction piracy prosecutions, and state practice shows that such prosecutions are quite rare. Ultimately, Part IV concludes that the existence of a high seas requirement for facilitators of piracy will have a very limited effect on impunity of facilitators. Part V provides some concluding remarks.

\section{THE SOURCE OF THE LEGAL UNCERTAINTY}

The respective histories of the crime of maritime piracy and the positive international law regulating maritime piracy overlap less than one might imagine. This is due to the fact that most positive international law dealing with piracy was codified during a time when actual incidents

disrupting the financial networks that support them."); see also ROBERT HAYWOOD \& ROBERTA SPIVAK, MARITIME PIRACY 106-11 (2012). 
of piracy were relatively rare.$^{10}$ One possible consequence of this lack of overlap is that the law of maritime piracy may not fully account for its modern nature. ${ }^{11}$ In its modern resurgence, pirate tactics changed markedly. Modern pirates rely much more on land-based facilitators, ranging from investors to hostage negotiators, than did their historical counterparts. As a result of this increased reliance, the question of whether inciters and intentional facilitators of piracy are subject to a high seas requirement has become as important as it is unsettled.

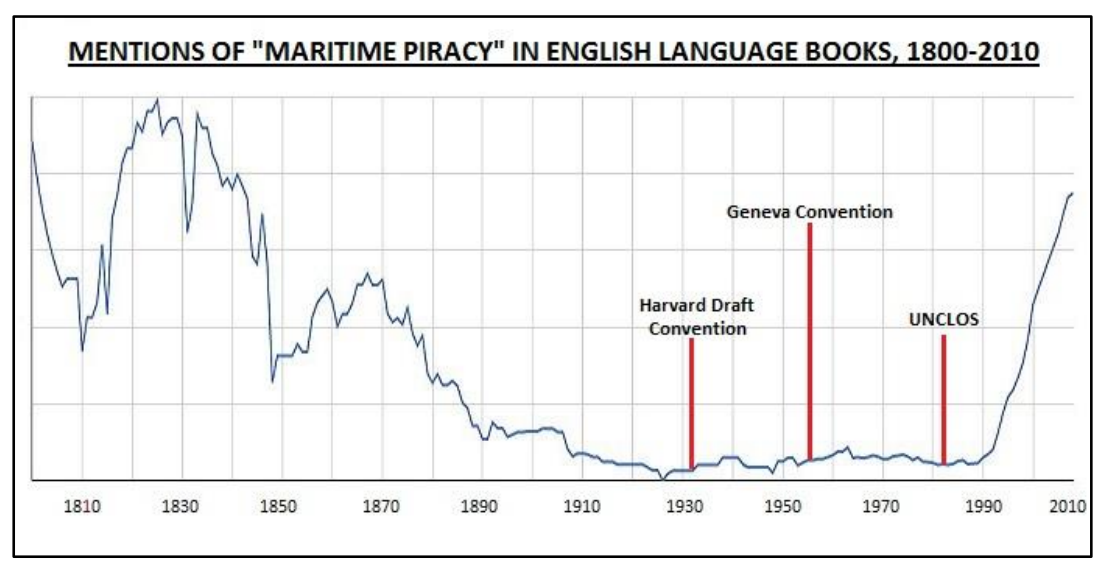

The above figure illustrates this phenomenon nicely. The line graph was made using Google's Ngram service, ${ }^{12}$ a tool that allows users to track the use of a given word or phrase in proportion to all words or phrases that appeared in eight million of the approximately twenty million books scanned by Google to date. ${ }^{13}$ The data suggest that maritime piracy was important until the turn of the twentieth century, after which it was given much less attention. The issue was not revived until the turn

10. See Scott Davidson, Dangerous waters: Combating maritime piracy in Asia, 9 ASIAN Y.B. INT'L L. 3, 5 (2000) ("There was a lack of attention devoted to the drafting of the provisions on piracy at UNCLOS III; it is attributable to the fact that, by that time, it was thought that maritime piracy was of such little practical concern ... as to require scant consideration.").

11. Id.

12. GOOGLE BOOKS NGRAM VIEWER, http://books.google.com/ngrams/ (last visited Feb. 4, 2013).

13. Ben Zimmer, Bigger, Better Google Ngrams: Brace Yourself for the Power of Grammar, The Atlantic (Oct. 18, 2012, 10:20 AM), http://www.theatlantic.com/ technology/archive/2010/10/bigger-better-google-ngrams-brace-yourself-for-the-power-ofgrammar/263487. 
of the twenty-first century. Nonetheless, as the chart also illustrates, virtually all of the positive international law concerning maritime piracy was considered and codified during piracy's wane. The narrative history of maritime piracy and the law governing such piracy mirrors the graphic representation above to a considerable extent.

The earliest references to piracy can be found in cuneiform writings dating around 2000 B.C., ${ }^{14}$ and robbery and violence on the high seas has captured the public imagination ever since. The popular image of pirates seems frozen around piracy's "Golden Age,"15 during which Barbary pirates played a role in the capture and enslavement of European travelers between the sixteenth and eighteenth centuries. ${ }^{16}$ This was undoubtedly the peak of piracy at sea. By 1932 the British historian Philip Gosse asserted that the age of piracy had "permanently ended."17 Indeed, twentieth century piracy was marked by sporadic, low-level attacks such that Gosse's 1932 assertion began to appear quite prescient. ${ }^{18}$ However, the early twenty-first century saw a troubling resurgence of maritime piracy, particularly off the horn of Africa, where in 2010 pirates attacked 445 ships, hijacked 53 ships, and captured 1,181 hostages. ${ }^{19}$ After a seventy year lull that occurred roughly between 1930 and 2000, maritime piracy was once again a practical issue for lawmakers and lawyers to grapple with.

Early on, the positive law that criminalized maritime piracy closely tracked the crime it attempted to regulate. Though pirates had been executed for millennia regardless of their nationality, Cicero is widely regarded as coining the phrase communis hostis omnium, or "common enemies of the world" in the first century B.C. to describe pirates as criminals of a fundamentally international character. ${ }^{20}$ Just as piracy experienced its "Golden Age" between the sixteenth and eighteenth

14. HAYWOOD \& SPIVAK, supra note 9, at 24.

15. Frank Sherry, Raiders and Rebels: The Golden Age of Piracy 7 (1986).

16. See Robert C. Davis, Christian Slaves, Muslim Masters: White Slavery IN THE MEDITERRANEAN, THE BARBARY COAST, AND ITALY, 1500-1800 141 (2003).

17. Philip Gosse, The History of Piracy 297-98 (1932).

18. See, e.g., Andrew Mwangura, Indian Ocean Piracy: 1990-2001, ECOP (Sept. 2, 2001), http://www.ecop.info/english/ind-oce-pir-1990-2001.htm (noting that only six pirate attacks occurred off the coast of Somalia between 1990 and 2001).

19. ICC Int'L Mar. Bureau Ann. Rep. 1 Jan.-31 DeC. 2010, Piracy and Armed RobBery AgAinst ShIPS (Jan. 2011) (on file with the author); see also Pirates seized record 1,181 hostages in 2010-report, BBC News (Jan. 18, 2011, 5:23 AM), http://www. bbc.co.uk/news/world-africa-12214905.

20. See M. Tullius Cicero, Cicero in Twenty-Eight Volumes: De Officils [ON DutiES] 385 (Walter Miller trans., 1913). 
centuries, early transnational regulation of piracy peaked in 1684 when the English Parliament passed An Act for the More Effectual Suppression of Piracy. This act established Vice Admiralty Courts throughout the British Empire in an attempt to sentence pirates. ${ }^{21}$ Several centuries later, only five years before Philip Gosse proclaimed piracy dead, the International Court of Justice found that maritime piracy was a crime against the law of nations, noting, "in its jurisdictional aspects, [piracy] is sui generis." 22

Yet during the twentieth century, the practice of maritime piracy began to diverge from its regulation. Though the actual incidence of piracy dropped markedly between 1930 and 2000, it was during this period that the international law of maritime piracy - including its definition-was codified and ultimately accepted as part of customary international law. The modern definition of piracy was first announced in a comprehensive manner as part of the 1932 Harvard Draft Convention on Piracy. ${ }^{23}$ It was then modified slightly by the International Law Commission in 1956 for inclusion in the 1958 Geneva Convention on the High Seas, ${ }^{24}$ and was subsequently copied verbatim from the Geneva Convention into the United Nations Convention on the Law of the Sea (UNCLOS) in $1982 .{ }^{25}$ By the year 2000, 134 countries had ratified UNCLOS. ${ }^{26}$ Today, even countries that have not ratified the treaty, such as the United States, have accepted the UNCLOS definition of piracy as an accurate reflection of customary international law. ${ }^{27}$

At the beginning of the twenty-first century, however, high seas piracy returned in a different, less centralized form from the one it took in years prior. Historically, maritime piracy occurred entirely at sea, as the pirate ship approached the victim ship, boarded it, robbed it, and sailed away. Today, Somali piracy, which represents over half of contemporary global attacks, ${ }^{28}$ more closely resembles an organized crime syndicate than the

21. An Act for the More Effectual Suppression of Piracy, in 3 BRITISH PIRACY IN THE Golden Age: History AND InTERPRETAtion, 1660-1730, at 59-60 (Joel H. Baer ed., 2007).

22. S.S. "Lotus" (Fr. v. Turk.), Judgment No. 9, 1927 P.C.I.J. (Ser. A) No. 10, at 70 (Sept. 7).

23. Harvard Law School, Draft Convention on Piracy, with Comment, 26 AM. J. INT'L L. 739, 749 (Supp. 1932) [hereinafter Harvard Draft Convention].

24. Geneva Convention on the High Seas, Apr. 29, 1958, 450 U.N.T.S. 11 [hereinafter Geneva Convention].

25. UNCLOS, infra note 32 .

26. See Chronological lists, infra note 34 .

27. See U.S. DigeST OF INT'L LAW, infra note 34.

28. 2011 Piracy Attacks Totaled 439; 275 off Somalia: ICC/IMB Report, INS. J. (Jan. 19, 2012), http://www.insurancejournal.com/news/ international/2012/01/19/231822.htm (noting that Somali pirates accounted for approximately 54\% of attacks on ships in 2011). 
antics of Captain Jack Sparrow. Rather than simply robbing the victim ship, Somali pirates board a large merchant vessel and hold its cargo and crew hostage, reaping ransoms that averaged around \$5 million in 2011. ${ }^{29}$ Moreover, modern pirates rely on territorially-based support, which comes from financiers on the front end, ${ }^{30}$ local suppliers of provisions during the ordeal, and hostage negotiators on the back-end. ${ }^{31}$ In fact, due to the relative abundance of Somalis willing to act as low-level pirates, many view the prosecution of land-based operators as the most effective use of judicial mechanisms to end the scourge of piracy. ${ }^{32}$

In sum, pirates' shifting tactics have led to a great deal of uncertainty around a high seas requirement for pirate facilitators. Therefore, a definitive answer to the question of jurisdiction is more important than ever. The following section seeks to answer the question in a way that, even if not definitive, should provide a starting point for further consideration and debate.

\section{A High SEAs REQUiREMENT FOR FACILITATION OF PIRACY JURE GENTIUM}

It is abundantly clear that piracy under the law of nations, or piracy jure gentium, is a crime of universal jurisdiction. ${ }^{33}$ It is equally clear that

29. Anna Bowden \& Shikah Basnet, The Economic Cost of Somali Piracy 2011 at 11 (One Earth Future Found., Working Paper, 2011) [hereinafter ECOP], available at http:// oceansbeyondpiracy.org/sites/default/files/economic_cost_of_piracy_2011.pdf [hereinafter ECOP].

30. See, e.g., Anthony O'Donnell, Pirate Financiers See Robust Returns in Tough Economy, InS. J. (Sept. 19, 2012), http://www.insurancetech.com/security/pirate-financierssee-robust-returns-in/240007590.

31. See, e.g., Sarah Wolfe, Somali pirate gets 12 life terms in boat hijackings, GloBAl Post (Aug. 13, 2012, 4:48 PM), http://www.globalpost.com/dispatch/news/regions/ americas/united-states/120813/somali-pirate-gets-12-life-terms-boat-hijackings; Toan QuyDo et al., The Pirates of Somalia: Ending the Threat, Rebuilding a Nation at xxiv (World Bank Report, 2013) [hereinafter World Bank Report], available at http://www-wds.worldbank. org/external/default/WDSContentServer/WDSP/IB/2013/05/06/00033303720130506120556/ Rendered/PDF/767130WP0REPLA0alia0main0report0web.pdf.

32. See Shapiro, supra note 9; see also HAYWOOD \& SPIVAK, supra note 9.

33. E.g., United Nations Convention on the Law of the Sea art. 105, Dec. 10, 1982, 1833 U.N.T.S. 397 [hereinafter UNCLOS] ("On the high seas, or in any other place outside the jurisdiction of any State, every State may seize a pirate ship or aircraft, or a ship or aircraft taken by piracy and under the control of pirates, and arrest the persons and seize the property on board. The courts of the State which carried out the seizure may decide upon the penalties to be imposed ...."). 
the definition of piracy under customary international law is reflected in art. 101 of the United Nations Convention on the Law of the Sea (UNCLOS), ${ }^{34}$ which states:

Piracy consists of any of the following acts:

(a) any illegal acts of violence or detention, or any act of depredation, committed for private ends by the crew or the passengers of a private ship or a private aircraft, and directed:

(i) on the high seas, against another ship or aircraft, or against persons or property on board such ship or aircraft;

(ii) against a ship, aircraft, persons or property in a place outside the jurisdiction of any State;

(b) any act of voluntary participation in the operation of a ship or of an aircraft with knowledge of facts making it a pirate ship or aircraft;

(c) any act of inciting or of intentionally facilitating an act described in subparagraph (a) or (b). ${ }^{35}$

The outer bounds of universal jurisdiction over maritime piracy, however, are much less apparent. Particularly, it remains an open question whether an inciter or intentional facilitator of piracy (hereinafter simply referred to as a "facilitator") must be physically present on the high seas to commit piracy jure gentium and therefore be subject to universal jurisdiction.

The Vienna Convention on the Law of Treaties applies a general rule of interpretation that the language of treaties is to be primarily interpreted in accordance with the ordinary meaning of the terms used in the context of the treaty as a whole. ${ }^{36}$ If this general approach leaves the meaning of the terms in question ambiguous or obscure, the Vienna Convention states, "[r]ecourse may be had to ary means of interpretation, including

34. See, e.g., Office of the Legal Adviser, U.S. Dep't of State, Digest of United States PRACTICE IN InTERnAtional Law: 2010, 111 (Elizabeth R. Wilcox ed., 2011) [hereinafter U.S. DIGEST OF INT'L LAw], available at http://www.state.gov/documents/ organization/179316.pdf ("[T]he actions and statements of the Executive Branch over more than six decades reflect the consistent U.S. view that [the UNCLOS art. 101] definition is both reflective of customary international law and universally accepted by states."); see also U.N. Division for Ocean Affairs and the Law of the Sea, Chronological lists of ratifications of, accessions and successions to the Convention and the related Agreements as of 23 January 2013 (Jan. 23, 2013), http://www.un.org/ Depts/los/reference_files/chronological_lists_of ratifications.htm [hereinafter Chronological lists] (listing the $1 \overline{6} 5$ states that have ratified UNCLOS).

35. UNCLOS, supra note 33, art. 101.

36. Vienna Convention on the Law of Treaties art. 31, May 23, 1969, 1155 U.N.T.S. 331. 
the preparatory work of the treaty and the circumstances of its conclusion ...." ${ }^{37}$

Although scholars have rightly pointed out that the Vienna Convention is not the sole authority of treaty interpretation under international law, ${ }^{38}$ it is an excellent starting point for any interpretive endeavor. Moreover, it is especially well suited to the task at hand due to the relationship between UNCLOS and customary international law. With the Vienna Convention's prescriptions in mind, this section examines the plain language, statutory context, drafting history, and underlying policy rationale behind UNCLOS art. 101(c) and concludes that, although the question remains one to be answered by state practice, a high seas requirement for pirate facilitators appears to exist under international law.

\section{A. The Plain Language of UNCLOS Art. 101 is Ambiguous as to a High Seas Requirement}

Opponents of a high seas requirement contrast the language of UNCLOS arts. 101(a) and 101(c) as their primary argument against such a requirement. The phrase, "on the high seas," opponents note, is present in art. 101(a) ${ }^{39}$ and absent in art. 101(c) ${ }^{40}$ This phrase carries an enormous amount of weight in opponents' arguments, who assert that the only plausible reading of the divergence between arts. 101(a) and (c) - which address direct perpetrators of piracy and facilitators of piracy, respectively - is that a high seas requirement exists for direct perpetrators and not for facilitators. Proponents of a high seas requirement for facilitators offer an alternative plausible reading of the text: that "on the high seas" was meant to differentiate high seas piracies from those occurring on terra nullius. These dual readings render the text of UNCLOS art. 101 ambiguous as to a high seas requirement for facilitators.

The strongest argument against a high seas requirement for pirate facilitators comes from a purely textual analysis, contrasting the language of UNCLOS art. 101(a) with the language of UNCLOS art. 101(c). Art. 101(a) relates to the actual perpetrators of piracy and states, in pertinent part, that "[p]iracy consists of . . . any illegal acts of violence or detention ...

37. Id. art. 32 .

38. E.g., Zhang Nai-gen, On International Law of Treaty Interpretation, 6 CAN. Soc. SCI., no. 6, 2010, at 16-17 (describing alternative methods of treaty interpretation).

39. UNCLOS, supra note 33, art. 101(a).

40. Id. art. $101(\mathrm{c})$. 
directed ... on the high seas, against another ship or aircraft, or against persons or property on board such ship or aircraft ... [or] against a ship, aircraft, persons or property in a place outside the jurisdiction of any State. ..." ${ }^{41}$ Contrast the language in art. 101(a) with that contained in 101(c), the section concerning facilitators, which says that piracy also consists of "... any act of inciting or intentionally facilitating an act described in subparagraph (a) ...."42

Conspicuously absent from art. 101(c), opponents argue, is the modifier "on the high seas" contained in art. 101(a) and applied to direct perpetrators. ${ }^{43}$ From this discrepancy, opponents conclude that UNCLOS creates discrete piracy offenses, one of which is governed by art. 101(a) and contains a high seas requirement and another that is governed by art. 101(c) and contains no such requirement. ${ }^{44}$ They argue that, if acts of facilitation must occur on the high seas along with direct acts of perpetration, the "high seas" language used in UNCLOS art. 101(a)(i) would be rendered otiose. ${ }^{45}$ However, there is an equally plausible reading of the plain language of UNCLOS art. 101 that leaves room for a high seas requirement for pirate facilitators.

Under this alternative reading, there are three classes of acts that constitute piracy jure gentium - direct commission, voluntary participation in the operation of a pirate ship, and acts of facilitation - and each must be committed from the high seas or a place outside the territorial jurisdiction of any state for universal jurisdiction to attach. For proponents, the presence of the phrase, "[o]n the high seas" in art. 101(a)(i) reflects the drafters' concern with clarifying that piracy jure gentium could be committed against victims on the high seas or on terra nullius, the latter case being described in UNCLOS art. 101(a)(ii) as "a place outside the

41. UNCLOS, supra note 33, art. 101(a).

42. Id. art. 101(c).

43. Id. art. 101(a), (c).

44. See Douglas Guilfoyle, Committing Piracy on Dry Land: Liability for Facilitating Piracy, EJIL: TALK! (July 26, 2012), http://www.ejiltalk.org/committingpiracy-on-dry-land-liability-for-facilitating-piracy/; see also Roger L. Phillips, Intentional Facilitation and Commission of Piracy as part of a Joint Criminal Enterprise, CoMmUNIS Hostis OMNIUM (July 26, 2012), http://piracy-law.com/2012/07/26/intentional-facilitationand-commission-of-piracy-as-part-of-a-joint-criminal-enterprise/; Roger L. Phillips, Pirate Accessory Liability: Developing a Modern Legal Regime Governing Incitement and Intentional Facilitation of Maritime Piracy, 25 FLA. J. INT'L L. 271, 293-94 (2013), available at http://ssrn.com/abstract=2158023; Int'l Mar. Org., U.N. Division for Ocean Affairs and the Law of the Sea, Piracy: elements of national legislation pursuant to the U.N. Convention of the Law of the Sea, 1982, at 4 n.15, LEG 98/8/1 (May 17, 2011) [hereinafter IMO, Piracy], available at http://www.un.org/Depts/los/piracy/circular_letter 3180.pdf (noting that art. 101(c) does "not explicitly set forth any particular geographic scope").

45. See Guilfoyle, supra note 40 (in the comments section following the article). 
jurisdiction of any State." 46 In other words, "on the high seas" refers more to the location of the victim than the perpetrator of piracy jure gentium.

Support for such a reading can be found both in the overall structure of the article and through a close reading of sections (a)(i) and (a)(ii). As for the overall structure, the chapeaux to art. 101 clearly states, "[p]iracy consists of the following acts ...." ${ }^{47}$ Thus, the plain language of the chapeaux more strongly supports the view of three separate acts constituting a single international offense rather than three separate international offenses with discrete jurisdictional requirements. Additionally, there is a great deal of substantive parallelism in sections (a)(i) and (a)(ii) suggesting that they serve to describe two contexts in which piracy jure gentium could occur, leading to the conclusion that "on the high seas" has nothing to do with facilitators.

Art. 101(a)(i) refers to attacks "directed ... on the high seas, against another ship or aircraft, or against persons or property on board such ship or aircraft." 48 This subsection contains a geographic limitation ("on the high seas") and a description of possible objects of piracy ("another ship or aircraft, or ... persons or property on board such ship or aircraft."). ${ }^{49}$ Similarly, art. 101(a)(ii) contains a geographic limitation ("in a place outside the jurisdiction of any State") alongside a description of the possible objects of an attack ("a ship, aircraft, persons or property"). ${ }^{50}$

To be sure, the substantive parallelism described above would be more readily apparent if it were coupled with structural parallelism between arts. 101(a)(i) and (ii). For example, if art. 101(a)(i) read, "directed ... against another ship or aircraft, or against persons or property aboard such an aircraft, on the high seas," the geographic and objective directives contained in both sections would be written in the same order. The converse is also true. If art. 101(a)(ii) read, "directed ... in a place outside the territorial jurisdiction of any State, against a ship, aircraft, persons, or

46. UNCLOS, supra note 33, art. 101; see also Report of the International Law Commission to the General Assembly, [1956] 2 Y.B. Int'1 L. Comm'n 253, cmt. 4, at 282, U.N. Doc A/3159 (1956) [hereinafter 1956 ILC Draft Articles], available at http://untreaty.un.org/ilc//texts/instruments/english/commentaries/8_1_8_2_1956.pdf ("In considering as 'piracy' acts committed in a place outside the juris diction of any State, the Commission had chiefly in mind acts committed by a ship or aircraft on an island constituting terra nullius or on the shores of an unoccupied territory.").

47. UNCLOS, supra note 33, art. 101.

48. Id. art. 101(a)(i).

49. Id.

50. Id. art. 101(a)(ii). 
property," it would be clear that arts. 101(a)(i) and (ii) do nothing more than differentiate piracy on the high seas from piracy on terra nullius, and include both in the definition of piracy jure gentium.

When viewed through the prism of the proponents' argument, the semantic differences between arts. 101(a)(i) and (ii) are so easily explainable they seem trite. First, art. 101(a)(i) refers to "another ship" while 101(a)(ii) simply mentions "a ship." 51 This discrepancy comes from the oft-cited "two-ship" requirement for piracy on the high seas, which is meant to exclude acts of mutiny from the definition of piracy jure gentium..$^{52}$ Such a requirement would be wholly irrational if applied on land, where ocean-going ships do not operate.

Second, art. 101(a)(i) modifies "persons or property" with "on board such ship," and no such modification is present in art. 101(a)(ii). ${ }^{53}$ This discrepancy has not been explicitly elucidated by the International Law Commission (ILC) or other legal scholars, but the plain language of the text suggests that the purpose of art. 101(a)(i)'s modification is to limit the potential objects of an act of piracy - apart from the victim ship itself - to persons and property physically aboard the victim ship, to the exclusion of property floating on the high seas. Ostensibly, such a provision would have been drafted to avoid the absurd result of a ship picking up seemingly abandoned cargo only to be accused of piracy under the law of nations by the ship from which that cargo was lost. Again, because ocean-going ships do not operate on land, such a modification would not be applicable to piracy on terra nullius. These

51. Id. art. 101(a).

52. 1956 ILC Draft Articles, supra note 46, cmt. 1 at 282 ("Acts committed on board a ship by the crew or passengers and directed against the ship itself, or against persons or property on the ship, cannot be regarded as acts of piracy."); IMO, Piracy, supra note 44, at 5 ("In order to constitute an act of piracy under UNCLOS, an attack on a ship must originate from another private ship or aircraft."); see also Diana Chang, Piracy Laws and the Effective Prosecution of Pirates, 33 B.C. INT'L \& CoMP. L. Rev. 273, 282 (2010); Jill Harrelson, Blackbeard Meets Blackwater: An Analysis of International Conventions that Address Piracy and the Use of Private Security Companies to Protect the Shipping Industry, 25 AM. U. INT'L L. REV. 283, 298 (2010); Milena Sterio, The Somali Piracy Problem: A Global Puzzle Necessitating a Global Solution, 59 AM. U. L. REV. 1449, 1468 (2010) ("[T]he Convention on the High Seas/UNCLOS piracy definition requires the presence of two vessels for an act to qualify as piracy - an aggressor vessel must attack a victim vessel. Therefore, if hijackers board the victim vessel at its last port of entry and then overpower the ship's crew on the high seas, this act would not constitute piracy under the Convention on the High Seas/UNCLOS definition, because only one vessel is involved. While some scholars have argued that two vessels may not be required under the Convention on the High Seas/UNCLOS definition, the majority view and the plain reading of these conventions indicate that their drafters envision the presence of two vessels in their definition of piracy.").

53. UNCLOS supra note 33, art. 101(a). 
differences explain the existence of both arts. 101(a)(i) and (a)(ii) as separate sub-sections and the textual differences between them. The asymmetrical drafting could quite plausibly have been the result of the drafters' preference for natural language over parallel sentence structure combined with the practical, mundane differences between piracy on the high seas and piracy committed on terra nullius.

Even still, the interpretive task proponents face is not to develop a unified theory of UNCLOS art. 101. Rather, it is limited to posing two plausible readings of art. 101 and rendering it ambiguous as to a high seas requirement for facilitators. Such ambiguity appears to be present. Opponents argue the purpose of the phrase "on the high seas" is to distinguish art. 101(a)(i) from art. 101(c) by placing a high seas requirement on direct perpetrators but not facilitators of piracy. Proponents assert its purpose is to distinguish art. 101(a)(i) from art. 101(a)(ii), thereby distinguishing piracy on the high seas from piracy on terra nullius and including both under the definition of piracy jure gentium. Opponents and proponents of a high seas requirement for facilitators are both able to advance a plausible reading of UNCLOS art. 101 that leads to the desired conclusion. This renders the meaning of art. 101 ambiguous as to a high seas requirement for facilitators and invites inquiry into other areas, including the UNCLOS provisions surrounding art. 101, to determine its true meaning.

\section{B. The Statutory Context Surrounding UNCLOS Art. 101 Suggests a High Seas Requirement}

Confining the analysis of a high seas requirement for pirate facilitators to the text of art. 101 alone might result in a split decision, but the context of art. 101 suggests piracy can only be committed on the high seas. Reading arts. 86, 100, and 105 of UNCLOS alongside the plain language of art. 101 provides evidence of the existence of a high seas requirement for facilitators of piracy jure gentium.

Art. 86, "Application of the provisions of this Part," introduces Part VII of UNCLOS. ${ }^{54}$ It reads, "[t]he provisions of this Part apply to all parts of the sea that are not included in the exclusive economic zone, in the territorial sea or in the internal waters of a State, or in the

54. Id. art. 86 . 
archipelagic waters of an archipelagic State." ${ }^{55}$ This provision seems to suggest that Part VII of UNCLOS, containing art. 101, only concerns itself with that which occurs outside the territorial jurisdiction of states. Indeed, one could go so far as to say that art. 86 incorporates itself by

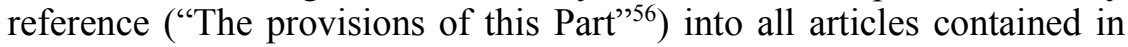
Part VII, including art. 101, and limits them to high seas acts.

Additionally, and perhaps more persuasively, art. 100 describes the duty of all States to cooperate in repressing piracy, but it limits that duty to piracy that occurs "on the high seas or in any other place outside the jurisdiction of any State." $" 57$ Art. 100 touches on a State's duty to repress piracy as opposed to its power to do so, ${ }^{58}$ but art. 105 continues where art. 100 leaves off and limits a State's power to seize "a pirate ship or aircraft, or a ship or aircraft taken by piracy" to seizures occurring "[o]n the high seas, or in any other place outside the jurisdiction of any State." 59 The importance of art. 105 cannot be overstated since it codifies universal jurisdiction over piracy jure gentium. ${ }^{60}$ Indeed, proponents could rely on a syllogism created by using UNCLOS arts. 101 and 105, respectively: the facilitation of piracy is itself piracy; universal jurisdiction over piracy only exists on the high seas; therefore, universal jurisdiction over facilitation only exists on the high seas.

For opponents, this sort of contextual argument may be viewed as overly simplistic and contrived. However, such complaints do not change the fact that there is an abundance of textual evidence surrounding art. 101 that suggests a high seas limitation and no statutory context whatsoever that suggests the absence of such a requirement. The implicit lack of a high seas requirement for facilitators would appear somewhat out of place in the context of the accompanying UNCLOS provisions. In many ways, the same conclusion can be reached by looking at the drafting history of UNCLOS art. 101.

55. Id.

56. Id.

57. Id. art. 100 .

58. Id.

59. Id. art. 105 .

60. Eugene Kontorovich, International Legal Responses to Piracy off the Coast of Somalia, AM. SoC'y INT'L L., 13 ASIL InSIGHTS (Feb. 9, 2009), http://www.asil.org/ insights090206.cfm; see also Robin GeIß \& ANNA PETRIG, PIRACY AND ARMEd RobBery at Sea: The Legal Framework for Counter-Piracy Operations in Somalia and THE GULF OF ADEN 149 (2011). 


\section{The Drafting History of UNCLOS Art. 101 Suggests a High Seas Requirement}

Like its statutory context, the drafting history of UNCLOS art. 101 is best characterized by evidence of a high seas requirement for pirate facilitators that is convincing, if not dispositive, particularly due to the lack of evidence mitigating such a requirement. This section traces the history of piracy's definition under international law as it relates to facilitators, beginning with the Harvard Draft Convention of $1932^{61}$ and ending fifty years later with UNCLOS. ${ }^{62}$ The language of the provisions contained in these instruments, when read alongside their respective commentaries, suggests that the line between the 1932 Draft Convention and UNCLOS is a relatively straightforward one, further suggesting that an inquiry into the drafting history of UNCLOS art. 101 could properly consider texts other than UNCLOS itself, where such an approach might otherwise be unwarranted.

\section{1932 Harvard Draft Convention on Piracy}

The starting point for any historical inquiry into UNCLOS art. 101 must be Harvard's 1932 Draft Convention on Piracy. ${ }^{63}$ The Draft Convention was the result of a League of Nations decision in 1924 to codify certain aspects of international law that were ripe for codification. ${ }^{64}$ After reviewing the existing state of the law and sending detailed questionnaires to various states, Harvard Law School completed its Draft Articles in anticipation of the first Conference for the Codification of International Law, to be held in $1930 .{ }^{65}$ Though this conference did not bear much fruit, Harvard's work on piracy formed the basis for subsequent discussions of the definition of piracy jure gentium by the International Law Commission, the United Nations, and its Member States.

Both the text and commentaries of the 1932 Draft Convention on piracy strongly suggest a high seas requirement for facilitators. As for the text of art. 3 of the Draft Convention, the article providing the definition

61. Harvard Draft Convention, supra note 23.

62. UNCLOS, supra note 33, art. 101.

63. Harvard Draft Convention, supra note 23.

64. Francis Deák, Book Review, 30 ColuM. L. Rev. 142, 142 (1930) (reviewing Harvard Law School, Research in International Law, Draft Conventions on Nationality, Responsibility of States, Territorial Waters).

65. Id. 
of piracy jure gentium, the drafters of the Harvard Convention chose the following language: "Piracy is any of the following acts, committed in a place not within the territorial jurisdiction of any state: ... [a]ny act of instigation or of intentional facilitation of [the direct commission of piracy or the knowing and voluntary operation of a pirate ship]." ${ }^{.66}$ This language makes a high seas requirement for facilitators quite plain, but the explanatory note accompanying art. 3 is even more explicit:

By this clause, instigations and facilitations of piratical acts, previously described in the Article are included in the definition of piracy. Obviously, convenience is served by this drafting device. The act of instigation or facilitation is not subjected to the common jurisdiction unless it takes place outside territorial jurisdiction. 67

Thus there can be no doubt that, at least as of 1932, the general consensus in the international community was that a facilitator of piracy must be physically present on the high seas in order to be subject to universal jurisdiction.

\section{1955 International Law Commission's Debate on Maritime Piracy}

The next time the definition of piracy under international law was taken up in a comprehensive fashion was in 1955 when the ILC was preparing its 1956 Articles concerning the Law of the Sea with commentaries. ${ }^{68}$ In preparing the Articles, the ILC not only used the Harvard Draft Convention as a starting point for its discussion on piracy ${ }^{69}$ but the Special Rapporteur also explicitly endorsed both the Harvard Draft Articles and the commentary attached to those articles:

Mr. FRANCOIS (Special Rapporteur) said that the subject of piracy had been studied very thoroughly by the Harvard Research Centre, to which Professor Joseph W. Bingham had submitted an exhaustive report, together with the text of a draft international convention consisting of 19 articles published by the Harvard Law School in 1932. He had felt that he could not do better than to take the principal articles in Professor Bingham's report, and the comments thereon, as a basis for the discussion on the subject of piracy, dealt with in articles 23 et seq of his own sixth report. His own draft had only six articles on piracy, namely, articles 23 to 28 . He had attached no comment to his individual articles, that appended to the Harvard articles, to which he referred members, being exhaustive and entirely satisfactory. 70

66. Harvard Draft Convention, supra note 23, at 743.

67. Id. at 822 (emphasis added).

68. 1956 ILC Draft Articles, supra note 46.

69. See Summary Records of the 290th Meeting, [1955] 1 Y.B. Int'l L. Comm'n 37, para. 29, at 39, U.N. Doc. A/CN.4/SER.A/1955.

70. Id. 
From that general endorsement, the Special Rapporteur then turned to the definition of piracy jure gentium, noting at the outset that the definition was:

based on three important principles: the principle that animus furandi did not have to be present; the principle that only acts committed on the high seas could be described as piracy; and the principle that acts of piracy were necessarily acts committed by one ship against another ship-which ruled out acts committed on board a single vessel.71

At this early stage, the ILC appeared to favor an even narrower conception of the high seas requirement for piracy jure gentium, citing Oppenheim for the proposition that even acts that occur "by descent from the open sea ... on an island unappropriated by a civilized Power" do not fall under universal jurisdiction. ${ }^{72}$ However, in an ILC meeting later that year, the Commission voted 11 to 1 in favor of assimilating "to the high seas territory not under the jurisdiction of any State" into the language of the draft. ${ }^{73}$

After introducing and describing the three overriding principles from the Harvard Draft Convention, the Special Rapporteur invited the ILC members to vote on each of the three principles one by one. ${ }^{74}$ Of the ten ILC members surveyed, two explicitly affirmed the Special Rapporteur's contention that universal jurisdiction over piracy was limited to acts on the high seas, seven were silent as to a high seas requirement, and only one specifically disavowed the high seas requirement. ${ }^{75}$ The lone dissenter, French jurist Georges Scelle, argued against a formalistic definition for piracy jure gentium and in favor of one based only on "the nature of the act." " However, Scelle was rebuffed by the Special Rapporteur, who opined that Scelle's position resulted from "his keen concern to establish an international police," and noted that the adoption of his proposal "would only serve to complicate the issue."77

Then, in a subsequent 1955 ILC meeting, the Commission considered a proposal by A. E. F. Sandström of Sweden to include acts perpetrated

71. Id. para. 32 , at 40 (emphasis added).

72. Id. para. 48 , at 41 .

73. Summary Records of the 292nd Meeting, [1955] 1 Y.B. Int'1 L. Comm'n 51, para. 24, at 53, U.N. Doc. A/CN.4/SER.A/1955.

74. Summary Records of the 290th Meeting, supra note 69, para. 55, at 42.

75. See id. paras. $56-84$, at $42-44$.

76. Id. para. 70 , at 43 .

77. Id. para. 79 , at 43 . 
along the coast and within a state's territorial jurisdiction in the definition of piracy. ${ }^{78}$ The renewed debate gave Scelle a chance to clarify his position. In doing so, he agreed that acts committed within the territorial jurisdiction of a state would come under the jurisdiction of the local courts. ${ }^{79}$ However, according to Scelle, questions of jurisdiction had no bearing on piracy's definition under international law. ${ }^{80}$ In explaining his own amendments, Sandström further stated that he wished to promote the progressive development of international law rather than codify existing law. ${ }^{81}$ Ultimately, Sandström's proposed expansion was struck down by six votes to four, with one abstention. ${ }^{82}$ The ILC debates began to move the issue of a high seas requirement for piracy jure gentium from the academic sphere to a more formalized structure.

\section{1956 ILC Draft Articles on Piracy}

The ILC's 1955 debate on maritime piracy culminated in the 1956 Articles concerning the Law of the Sea with commentaries ("Draft Articles"). Discussion of the Draft Articles, which were eventually incorporated into the 1958 Geneva Convention on the High Seas, echoes the ILC debates and stresses the importance of the Harvard Draft Convention. ${ }^{83}$ To wit, the first of the ILC's 1956 commentaries on piracy reads:

In its work on the articles concerning piracy, the Commission was greatly assisted by the research carried out at the Harvard Law School, which culminated in a draft convention of nineteen articles with commentary, prepared in 1932 under the direction of Professor Joseph Bingham. In general, the Commission was able to endorse the findings of that research. 84

Yet despite this endorsement, the ILC changed the form of its piracy definition by moving the phrase, "in a place outside the jurisdiction of any State" out of the chapeaux and into the body of the article. ${ }^{85}$ Opponents have cited this amendment as evidence of the uncertainty around whether the requirement survived the Harvard Draft Convention and 1955 ILC debates. ${ }^{86}$ However, the most natural reading of both the text

78. Summary Records of the 292nd Meeting, supra note 73, para. 9, at 52.

79. Id. para. 11 , at 52 .

80. Id.

81. Id. para. 16 , at 53

82. Id. para. 21 , at 53.

83. United States v. Hasan, 747 F. Supp. 2d 599, 619 (E.D. Va. 2010).

84. 1956 ILC Draft Articles, supra note 46, cmt. 1, at 282.

85. Id., art. 39, at 282

86. Jon Bellish, Breaking News from 1932: Pirate Facilitators Must Be Physically Present on the High Seas, EJIL: Talk! (Sept. 19, 2012), http://www.ejiltalk.org/breaking- 
and subtext of the ILC's commentary concerning the 1956 Draft Articles suggests the amendment was made to differentiate piracy committed on the high seas from that committed on terra nullius and to include them both within piracy's definition jure gentium. It therefore appears unlikely the ILC made the amendment to differentiate acts of direct perpetration from acts of facilitation and to place divergent jurisdictional limitations upon each.

The text of the ILC's commentary explicitly states, "[i]n considering as 'piracy' acts committed in a place outside the jurisdiction of any State, the Commission had chiefly in mind acts committed by a ship or aircraft on an island constituting terra nullius or on the shores of an unoccupied territory." 87 This intent is a clear departure from the language of the Harvard Draft Convention definition ("in a place not within the territorial jurisdiction of any state"), ${ }^{88}$ used in lieu of, not in addition to and distinct from, the phrase "on the high seas." Such a departure, if it were meant to be more substantive in nature, would undoubtedly have been worth noting in the commentary, especially in light of the ILC's strong general endorsement of the Harvard Draft Convention.

The subtext of the ILC's commentary on art. 39 of the Draft Articles further suggests that a high seas requirement for facilitators was incorporated into the 1956 Draft Articles. The ILC commentary begins by stating it "had to consider certain controversial points as to the essential features of piracy." 89 It went on to list the conclusions reached for each of the six points, namely that: 1) animus furandi is not required; 2) "private ends" are required; 3) piracy can only be committed by a private ship; 4) "[p]iracy can be committed only on the high seas or in a place situated outside the territorial jurisdiction of any State, and cannot be committed within the territory of a State or in its territorial sea"; 5) piracy can be committed from a ship or an aircraft, and; 6) acts committed on board a single ship cannot be regarded as piracy. ${ }^{90}$ Conspicuously absent from the list is any mention of a high seas requirement for facilitators, save for

news-from-1932-pirate-facilitators-must-be-physically-present-on-the-high-seas/ (comment by Douglas Guilfoyle, posted Sept. 20, 2012 at 11:22 AM).

87. 1956 ILC Draft Articles, supra note 46, cmt. 4, at 282 (noting that "outside the jurisdiction of any State" could also refer to attacks by aircraft over a larger unoccupied territory).

88. Harvard Draft Convention, supra note 23, at 743.

89. Id. cmt. 1, at 282 .

90. Id. 
the explicit affirmation that as a general proposition piracy can only be committed on the high seas or another place outside the territory of a single state. ${ }^{91}$ Thus, opponents' claim that the transformation in piracy's definition between the 1955 ILC preparatory debates and the 1956 Draft Articles is evidence of the demise of a high seas requirement for facilitators does not withstand close scrutiny.

\section{1958 Geneva Convention on the High Seas and UNCLOS}

The remaining history of piracy's definition under international law as it relates to incitement and intentional facilitation-from the 1956 ILC Draft articles to UNCLOS in 1982 - is relatively straightforward. Art. 39 of the 1956 Draft Articles appeared in the 1958 Geneva Convention on the High Seas with several superficial grammatical changes and only one substantive change: that an aircraft can be the victim of piracy on the high seas. ${ }^{92}$ The definition in the 1958 Geneva Convention was copied verbatim into UNCLOS art. 101, where it has remained untouched and

91. Bellish, supra note 86 .

92. Compare 1956 ILC Draft Articles, supra note 46, art. 39, with Geneva Convention, supra note 24, art. 15.

Article 39:

Piracy consists of any of the following acts:

(1) Any illegal acts of violence, detention or any act of depredation, committed for private ends by the crew or the passengers of a private ship or a private aircraft, and directed:

(a) On the high seas, against another ship or against persons or property on board such a ship;

(b) Against a ship, persons or property in a place outside the jurisdiction of any State.

(2) Any act of voluntary participation in the operation of a ship or of an aircraft with knowledge of facts making it a pirate ship or aircraft.

(3) Any act of incitment or of intentional facilitation of an act described in sub-paragraph 1 or sub-paragraph 2 of this article.

1956 ILC Draft Articles, supra note 46, art. 39.

Article 15:

Piracy consists of any of the following acts:

1. Any illegal act of violence, detention or any act of depredation, committed for private ends by the crew or the passengers of a private ship or a private aircraft, and directed:

(a) On the high seas, against another ship or aircraft, or against persons or property on board such ship or aircraft;

(b) Against a ship, aircraft, persons or property in a place outside the jurisdiction of any State;

2. Any act of voluntary participation in the operation of a ship or of an aircraft with knowledge of facts making it a pirate ship or aircraft;

3. Any act of inciting or of intentionally facilitating an act described in subparagraph 1 or sub-paragraph 2 of this article.

Geneva Convention, supra note 24, art. 15. 
seldom discussed since its entry into force in $1982 .{ }^{93}$ To illustrate this, despite its generally thorough nature, the seven volume treatise, United Nations Convention on the Law of the Sea 1982: A Commentary, gives UNCLOS art. 101(c) relatively brief treatment, noting only that the section exists, that attempts to commit piracy are not explicitly included in the article's application, and that, per UNCLOS art. 58, para. 2, the definition of piracy applies to acts that take place within the exclusive economic zone (EEZ) of a single state. ${ }^{94}$

Opponents will point to piracy's treatment during the drafting of UNCLOS alongside the chart in Part II, supra, and argue that the above historical characterization should not be given much weight. They might argue that, rather than speaking to the intent of the drafters, the history of piracy's definition jure gentium is the result of poor workmanship, which itself stems from the simple fact that maritime piracy was not of much import during the development of the positive international law on the topic. ${ }^{95}$ Piracy's reemergence was not predicted by many, if any, scholars or practitioners of international law.

Yet the available evidence, though weaker than a strong proponent of a high seas requirement might like, counsels against such an interpretation. There is no question that the drafters of the Harvard Convention believed a high seas requirement for facilitators existed, and there is nothing in the subsequent history suggesting a deviation from that position. The ILC explicitly endorsed the Harvard Draft Convention, debated the merits of a high seas requirement, and seemed to conclude that, at least as a matter of international law as it existed in 1955, universal jurisdiction only existed over acts committed on the high seas. One year after the 1955 debate, the ILC re-worked the structure of the definition of piracy, but the available evidence suggests that this modification left unchanged the proposition that universal jurisdiction could not be asserted on individuals operating solely within the jurisdiction of a state. There is nothing in the remaining history to suggest that subsequent stewards of the definition of piracy jure gentium ever intended to deviate from the guidance contained in the 1932 Harvard Draft Convention.

93. UNCLOS, supra note 33, art. 101.

94. 3 CENTER FOR OCEANS LAW AND Policy, UNIVERSITY OF Virginia SCHOOL OF LaW, United Nations Convention on the LaW of the Sea 1982: A Commentary 202 (Myron H. Nordquist, Satya N. Nandan \& Shabtai Rosenne eds., 1995).

95. See, e.g., Bellish, supra note 86 (comment by Douglas Guilfoyle, posted Sept. 20, 2012 at 11:22 AM). 
Moreover, even if it could be said with certainty that drafters from 1932 to 1982 simply failed to consider a high seas requirement for facilitators, such a fact would hardly be sufficient evidence that the requirement no longer exists. Customary international law cannot develop by accident but requires state practice and opinio juris. ${ }^{96}$ The question of whether a high seas requirement for facilitators of piracy exists should not be answered using policy-favorable readings of UNCLOS's text or its drafting history. Rather, the inquiry should be based on a disinterested analysis of the text, statutory context, and drafting history of UNCLOS alongside the underlying policy rationale behind asserting universal jurisdiction over maritime piracy. This final source of analysis - underlying policy rationale - will be discussed in the following section.

\section{The Possible Policy Rationales Behind Universal Jurisdiction Over Piracy Suggest a High Seas Requirement}

Though on balance, the textual, contextual, and historical analyses above suggest the existence of a high seas requirement for facilitators, inquiry into the underlying policy rationale behind piracy's status as a crime of universal jurisdiction may provide some additional insight. This section will discuss six potential rationales for establishing universal jurisdiction over pirates, explain the respective merits and demerits of each, and consider their implications vis-à-vis a high seas requirement for facilitators. The conclusion that flows from this analysis is similar to that which resulted from the previous inquiries. Foundational principles of international law combine with a faithful reading of history to make a reasonably convincing case in favor of a high seas requirement, with only a policy-favorable reading of that same history standing to rebut the case.

\section{Inherent Heinousness - Against a High Seas Requirement}

The most prolific, indeed the prevailing, rationale advanced to explain piracy's status as the paradigmatic universal jurisdiction offense is the alleged inherent heinousness of the crime. ${ }^{97}$ This argument has carried a

96. See Statute of the International Court of Justice art. 38, June 26, 1945, 59 Stat. 1031, 33 U.N.T.S. 993; PARRY AND GRANT ENCYCLOPAEDIC DICTIONARY OF INTERNATIONAL LAw 109 (John P. Grant \& J. Craig Barker eds., 2d ed. 2004); C.M. Chinkin, The Challenge of Soft Law: Development and Change in International Law, 38 INT'L \& COMP. L.Q. 850, 857 (1989); Josef L. Kunz, The Nature of Customary International Law, 47 AM. J. INT'L L. 662, 665 (1953).

97. See, e.g., Emmerich DE VAtTel, LAw of Nations bk. I, § 233 (1833) ("[A]lthough the justice of each nation ought in general to be confined to the punishment of crimes committed in its own territories, we ought to except from this rule those villains, who, by the nature and habitual frequency of their crimes, violate all public 
great deal of weight because it is virtually undisputed that the crime of piracy is the doctrinal foundation for the more recent push towards universal jurisdiction over indisputably heinous crimes such as genocide and torture.$^{98}$ If it were true that piracy was the first crime to be viewed by the international community as truly reprehensible, that fact would militate against a high seas requirement for pirate facilitators. If universal jurisdiction is predicated upon piracy's heinousness, and customary international law included facilitation of piracy in the definition of piracy itself, it would be difficult to argue that something as formalistic as a facilitator's presence within the territorial jurisdiction of a state protected him from a charge of piracy jure gentium.

Despite its success, this analogy appears overworked. According to former U.S. Secretary of State Henry Kissinger, the heinousness analogy "has spread with extraordinary speed and has not been subjected to systematic debate, partly because of the intimidating passion of its

security, and declare themselves the enemies of the human race. Poisoners, assassins, and incendiaries by profession, may be exterminated wherever they are seized; for they attack and injure all nations, by trampling under foot the foundation of their common safety. Thus, pirates are sent to the gibbet by the first into whose hands they fall."); 15 T.B. HowelL, The Trials of Major Stede Bonnet, and Thirty-three others, at the Court of Vice-Admiralty, at Charles-Town, in South-Carolina, for Piracy, A.D. 1718, in A Complete Collection of State Trials 1231, 1235 (1812) ("As to the heinousness or wickedness of [piracy], it needs no aggravation, it being evident to the reason of all men."); Program in Law and Pub. AfFairs, Princeton Univ., Princeton Principles ON UNIVERSAL JURISDICTION 45-47 (Stephen Macedo ed., 2001) [hereinafter PRINCETON PRINCIPLES], available at http://lapa.princeton.edu/hosteddocs/unive_jur.pdf, at 27 or 45 (listing piracy alongside slavery, war crimes, crimes against peace, crimes against humanity, genocide, and torture as "Serious Crimes Under International Law"); A. Hays Butler, The Doctrine of Universal Jurisdiction: A Review of the Literature, 11 CRIM. L.F. 353, $356(2000)$ (describing a rationale that "focuses on the nature of the offence, rather than its locale.").

98. See, e.g., In re Extradition of Demjanjuk, 612 F. Supp. 544, 556 (N.D. Ohio 1985) ("Piracy is the paradigm of an offense 'against the common law of nations'... The principle that the perpetrators of crimes against humanity and war crimes are subject to universal jurisdiction found acceptance in the aftermath of World War II."); Filartiga v. Pena-Irala, 630 F.2d 876, 890 (2d Cir. 1980) ("[T]he torturer has become-like the pirate and slave trader before him-hostis humani generis, an enemy of all mankind."); Prosecutor v. Furundzija, Case No. IT-95-17/1-T, Judgment, 147 (Int'1 Crim. Trib. for the Former Yugoslavia Dec. 10, 1998) (analogizing torture to piracy as it relates to universal jurisdiction); Eugene Kontorovich, The Piracy Analogy: Modern Universal Jurisdiction's Hollow Foundation, 45 HARV. INT'L L.J. 183, 195-96 (2004) [hereinafter Piracy Analogy] (describing the evolution of the piracy analogy). 
advocates." 99 Professor Eugene Kontorovich summarized the troubled nature of the heinousness rationale best, saying it "begins with what many international lawyers believe should be the proper model of [universal jurisdiction] - the moral enormity of the offense. Defining [universal jurisdiction] as based on heinousness, the account then anachronistically shoehorns piracy [universal jurisdiction] into that model." 100

The central flaw with the heinousness argument for universal jurisdiction over piracy is that it woefully ignores the state practice of supporting privateers, who performed the same acts as pirates with the same motives, but who did so under the color of state authority. ${ }^{101}$ Rather than being put to death for piracy, privateers were deemed to have not committed a crime at all. ${ }^{102}$ All nations acknowledged the right of other nations to authorize such commerce raiding, and privateering was a valid defense against charges of piracy. ${ }^{103}$

The central consideration underlying the rebuttal of the heinousness theory is that there was very little functional difference between the individualized acts and intentions of pirates and privateers. ${ }^{104}$ Both groups stole goods from non-combatants through the threat of violence, and made good on that threat if goods were not turned over. ${ }^{105}$ Similarly, both groups

99. Henry A. Kissinger, The Pitfalls of Universal Jurisdiction, 80 FoREIGN AFF., July-Aug. 2001, at 86, 86, available at http://www.globalpolicy.org/component/content/ article/163/28174.html; see also Steven W. Becker, Universal Jurisdiction: How Universal Is It? A Study of Competing Theories, 12 PALESTINE Y.B. InT'L L. 49, 57 (2002/2003) (noting the flawed nature of the heinousness rationale).

100. Eugene Kontorovich, Implementing Sosa v. Alvarez-Machain: What Piracy Reveals About the Limits of the Alien Tort Statute, 80 Notre Dame L. Rev. 111, 137 (2004) [hereinafter Implementing Sosa].

101. See Piracy Analogy, supra note 98, at 210 ("Privateering was a form of nationally sponsored piracy which reached its peak in the late 18th and early 19th centuries. Privateers engaged in the exact same conduct as pirates: seizing merchant shipping through threat of lethal force. Yet the latter were not subject to universal jurisdiction. They were not even regarded as criminals, and a captured privateer would eventually be repatriated to his home state.") (internal quotations omitted).

102. David Cordingly, Under the Black FlaG: The Romance and the Reality of Life AMONG THE PIRATES, at xvii-xviii (1995).

103. Piracy Analogy, supra note 98, at 210.

104. As will be explained in Part III(D)(3), infra, letters of marque and reprisal were accompanied by instructions limiting the nations whose ships a privateer could plunder, and the proceeds were distributed through a prize court. State sanction and formalized processes certainly distinguish privateering from piracy as a general conceptual matter. However, for the purposes of the inherent character of the acts and mental states under which the acts were committed, the two are nearly identical.

105. Manuel Schonhorn, Postscript to Daniel Defoe, A General History of the PYRATES 705 (Manuel Schonhorn ed., 1999) (1724) ("[I]t was the overwhelming numbers [of men] on a pirate ship that prevailed, and usually without violence."); Piracy Analogy, supra note 98, at 214 ("If a merchant vessel would not surrender, privateers, like pirates, would resort to arms."). 
plundered for their own pecuniary gain. ${ }^{106}$ These similarities did not go unnoticed. Courts openly recognized the similarity between piracy and privateering, describing the former as "privateering without a commission or letters of marque," 107 and noting that a commission to cruise determined whether one was a pirate or not. ${ }^{108}$ Yet the pirate was subject to a death sentence under universal jurisdiction while the privateer could receive no penalty under any theory of jurisdiction.

Logically, if the act of armed robbery at sea for personal pecuniary gain were so inherently heinous an act as to merit universal jurisdiction, states would not have sanctioned it through the issuance of letters of marque and reprisal. This purely formalistic approach to robbery at seabelies the notion that universal jurisdiction over piracy arose because of its heinousness. Although the heinousness rationale suggests the absence of a high seas requirement for facilitators, state practice strongly suggests that something other than the inherent heinousness of the offense was the basis for universal jurisdiction for piracy.

106. Piracy Analogy, supra note 98, at 214 ("After the prize proceeding, the government would take its share of the prize's value (usually ten percent) and the rest would be divided between the privateer's owners, officers, and crew in accordance with a formula set out in the ship's articles."). This is not to say that desire for personal pecuniary gain is required to satisfy the "private ends" requirement, which is much broader. It is only to say that personal pecuniary gain most certainly fits within the "private ends requirement." See, e.g., Harvard Draft Convention, supra note 23, at 857; Report of the Sub-Committee of the League of Nations Committee of Experts for the Progressive Codification of International Law, League of Nations Doc. C.196.M.70 1927 V, at 117 (1927) ("Certain authors take the view that desire for gain is necessarily one of the characteristics of piracy. But the motive of the acts of violence might be not the prospect of gain but hatred or a desire for vengeance. In my opinion it is preferable not to adopt the criterion of desire for gain, since it is both too restrictive and contained in the larger qualification 'for private ends.' It is better, in laying down a general principle, to be content with the external character of the facts without entering too far into the often delicate question of motives. Nevertheless, when the acts in question are committed from purely political motives, it is hardly possible to regard them as acts of piracy involving all the important consequences which follow upon the commission of that crime. Such a rule does not assure any absolute impunity for the political acts in question, since they remain subject to the ordinary rules of international law.").

107. H.M. Advocate v. Cameron \& Others, (1971) S.L.T. 202, 204 (Scot.).

108. United States v. Jones, 26 F. Cas. 653, 656 n.2 (C.C.D. Pa. 1813) (No. 15,494); see also United States v. The Ambrose Light, etc., 25 F. 408, 417 (S.D.N.Y. 1885); Davison v. Seal-Skins, 7 F. Cas. 192, 196 (C.C.D. Conn. 1835) (No. 3,661) (recounting how the U.S. Navy released "a nest of pirates" from custody upon learning that they had been acting under Argentinean commission). 


\section{Protecting the Freedom of Navigation-Against a}

High Seas Requirement

A separate, though closely related, account of universal jurisdiction over piracy is that common jurisdiction was deemed appropriate because pirates prey on global shipping lanes, disrupting the flow of international commerce, which all states have an interest in protecting. ${ }^{109}$ Like the heinousness rationale, universal jurisdiction based on the freedom of navigation would suggest that a high seas requirement for facilitators does not exist. If crimes affecting the freedom of navigation deserve universal jurisdiction, then it should not matter whether a pirate financier facilitates from land or the high seas.

In a sense, those who support this argument probably stand on more solid ground than those who support the heinousness rationale. Protecting international shipping lanes is based on a well-established principle of the Westphalian system - freedom of the high seas - announced by Hugo Grotius in the early 17 th century. ${ }^{110}$ The heinousness rationale, on the other hand, is based solely on an anachronistic reading of history driven by contemporary policy preferences.

Nonetheless, state practice during piracy's Golden Age undermines the freedom of navigation rationale in the same way it does the heinousness rationale. Since privateers and pirates performed the exact same acts for the exact same reasons, they both disrupted the freedom of navigation. Yet piracy was considered a crime of universal jurisdiction while privateering was not a crime at all. The freedom of navigation rationale, like the heinousness rationale, runs counter to the welldocumented state practice concerning privateers. A fair reading of history suggests that both rationales were developed long after universal jurisdiction was established over piracy. Neither rationale drove states' decision-making process when they made piracy the first and only crime of universal jurisdiction.

109. See, e.g., Harvard Law School, Draft Convention on Jurisdiction with Respect to Crime, with Comment, 29 AM. J. INT'L L. 435, 566 (Supp. 1935) ("The competence is perhaps better justified at the present time upon the ground that the punishable acts are committed upon the seas where all have an interest in the safety of commerce and where no State has territorial jurisdiction."); see also Georges Abi-Saab, The Proper Role of Universal Jurisdiction, 1 J. INT'L CRIM. JuST. 596, 599-600 (2003) (noting how piracy affects the international community at large, and that a state exercising universal jurisdiction over a pirate is acting on behalf of the community).

110. See Hugo Grotius, The Freedom of the Seas (James Brown Scott ed., Ralph Van Deman Magoffin trans., 1916). 


\section{Regulatory Capture - In Favor of a High Seas Requirement}

There is another potential explanation of why piracy was the sole crime of universal jurisdiction for centuries. Unlike the preceding two theories, this one fully accounts for the disparate treatment afforded to pirates and privateers. This rationale, if believed, counsels strongly in favor of a high seas requirement for facilitators. It may even suggest that piracy does not merit universal jurisdiction by modern standards. Simply stated, the theory is that piracy's status as a crime of universal jurisdiction was a form of regulatory capture by states over the privateering industry. Under this theory, states made a collective, mutually beneficial decision to allow other states to engage in privateering. This scheme provided for all the benefits of authorized privateering while simultaneously punishing with death those who engaged in unauthorized privateering, i.e., piracy, from which no state could derive benefit. The available historical evidence suggests that privateering provided states with extensive political and economic benefits, which gives substantial support for the theory of regulatory capture.

The two main evidentiary sources in support of the regulatory capture theory are the instructions that accompanied letters of marque and reprisal, and state practice as it relates to prize law. From the seventeenth to the nineteenth century, all seafaring states would issue letters of marque and reprisal, which permitted the holder to seize ships and property on the high seas. ${ }^{111}$ Often accompanying the letters of marque and reprisal were instructions listing the conditions upon which the letter was issued. ${ }^{112}$ Though the contents of the instruction varied greatly, it always included a provision limiting the privateer to attacking ships that belonged to enemies of the issuing state. ${ }^{113}$ This practice allowed issuing nations to exert political and even war-like pressure on geopolitical foes in peacetime and wartime alike. ${ }^{114}$ Indeed, even the nomenclature of the practice, letters of marque and reprisal, suggests a political purpose. Seafaring nations of the seventeenth, eighteenth, and nineteenth centuries saw privateering as a convenient political tool, one they were unafraid to use.

111. Piracy Analogy, supra note 98, at 211.

112. See id. at 213.

113. Id.

114. See id. ("The Articles of Confederation explicitly authorized 'granting letters of marque and reprisal in times of peace."'). 
In addition to political benefits, privateering produced lucrative gains for both the privateers and the authorizing states. After a privateer capture a ship, that ship and all the valuable property thereon were taken back to the authorizing state and brought before a prize court. ${ }^{115}$ There, a judge would determine whether the prize was taken in accordance with the instructions contained in the privateer's letter of marque. ${ }^{116}$ If it was, the court would sell the ship and distribute the proceeds of the sale to the privateers, reserving a percentage for the state (usually around ten percent). ${ }^{117}$ With the possibility of these funds flowing in fairly regularly simply upon issuing letters of marque, it takes no stretch of the imagination to see why such a financial arrangement seemed highly beneficial to the states that utilized it.

Understanding piracy in this way makes universal jurisdiction over pirates, and the uniform penalty of death imposed upon them, a relatively straightforward proposition. Seafaring nations decided, either collectively or simultaneously, that the political and economic benefits derived from a country's own privateering activities outweighed the possibility that their merchants would be plundered by another nation's privateers. However, the cost-benefit analysis shifted dramatically when sea robbers declined to follow the instructions on letters of marque, or sold the proceeds of a successful plunder themselves, keeping the ten percent commission out of their state's coffers. Thus, the seemingly formalistic distinction between pirates and privateers arose, a discrepancy that is no longer puzzling when viewed from the perspective of a rationally self-interested seafaring state of the seventeenth, eighteenth, and nineteenth centuries.

The proposition that regulatory capture supports universal jurisdiction over piracy is only a theory. Yet regulatory capture does a much better job in explaining how the similarities between privateers and pirates could coexist with such striking differences in treatment. If this theory proved to be true, there would be few left to defend piracy's status as a crime of universal jurisdiction, let alone the application of universal jurisdiction on facilitators operating within one state's territory. Universal jurisdiction over piracy would seem anachronistic and out of touch with modern international criminal law. The next section offers a more charitable explanation for piracy's status as the first crime of universal jurisdiction. It is at least as historically plausible as the theory of regulatory capture and leads to the same conclusion: that a high seas requirement for pirate facilitators exists under international law.

\footnotetext{
115. Id

116. Id.

117. Id. at 213-14
} 


\title{
4. Evidentiary Shortcut-In Favor of a High Seas Requirement
}

The fourth possible policy rationale for universal jurisdiction over piracy is qualitatively different from the three that precede it. Where the others treated universal jurisdiction as an extension of a state's traditional jurisdictional powers under international law, this evidentiary shortcut rationale treats universal jurisdiction as a proxy for those traditional jurisdictional powers. ${ }^{18}$ Like the theory of regulatory capture described above, this rationale has yet to take hold in most mainstream commentary. Yet the logic behind it is fairly intuitive, and it accords with the theory that states are rational actors. Professor Eugene Kontorovich, the original author of this theory, describes the impetus behind it succinctly:

\begin{abstract}
Because pirates injured many nations, many nations could exercise jurisdiction under traditional rules. However, proving the existence of jurisdiction in any specific cases could be very difficult. Pirate ships were almost never caught in the act; rather, they were apprehended when they returned to port and attempted to sell their booty. Unless the pirate ship was caught red-handed, the forum state might have little evidence as to what particular nations' ships the pirate had attacked. 119
\end{abstract}

In other words, absent universal jurisdiction, a prosecuting state would need to prove either the defendant's or the victim's nationality to assert criminal jurisdiction over that defendant. Asserting universal jurisdiction over piracy was simply a tool of convenience to bypass the difficulties associated with asserting criminal jurisdiction based on the nationality of the defendant or victim without knowledge of either of those facts.

Providing further evidence that such an evidentiary shortcut was needed is the fact that pirates and privateers alike worked hard to mask their identities. ${ }^{120}$ From flying multiple flags to repainting their ships, sea robbers were nothing if not devious in their attempts to obscure their national identities. ${ }^{121}$ With the nationality of the pirates and the victims

118. See Eugene Kontorovich, Universal Jurisdiction Over Non-Political Cases: An Evidentiary Theory of UJ 22 (Dec. 4, 2012) (unpublished manuscript) (on file with author) ("Universal jurisdiction over piracy is best understood as an evidentiary rule. It facilitated the prosecution of the crime in cases where traditional territorial or nationality jurisdiction existed but would be very difficult to affirmatively prove.") [hereinafter Evidentiary Theory].

119. Id. at 24 (emphasis in original).

120. Id.

121. See Matthew P. Harrington, The Legacy of the Colonial Vice-Admiralty Courts (Part II), 27 J. MAR. L. \& COM. 323, 342 (1996). 
totally obscure - facts that a prosecutor must prove to assert traditional criminal jurisdiction - courts were left to assign jurisdiction based on the nature of the crime rather than the nationalities of the individuals involved in it.

Yet none of the problems associated with identifying pirates' or victims' nationalities would apply to land-based facilitators. First, there will always be at least one clear and provable traditional jurisdictional nexus - the territory from which the facilitator operates - that could be relied upon. Additionally, reaching a land-based pirate facilitator and building a successful case against him would necessarily require fairly specific information about the pirates he facilitated. Such information would almost certainly include the pirates' or victims' nationalities. If universal jurisdiction over piracy is thought of as a tool of convenience, and none of the features giving rise to the need for that tool are present in the case of land-based facilitators, it stands to reason that universal jurisdiction was never intended to apply to land-based facilitators.

If the two previous theories or regulatory capture and evidentiary shortcut are slightly obscure, the next two are squarely mainstream. Both justifications, practical difficulty of enforcement and lack of implications on sovereignty, find support in the works of scholars and jurists alike and strongly suggest that a high seas requirement for facilitators exists.

\section{Difficulty of Enforcement-In Favor of a High Seas Requirement}

The first of the widely-advanced rationales for universal jurisdiction over piracy that suggests a high seas requirement for facilitators is based on the practical difficulty of capturing and trying pirates using traditional law enforcement mechanisms. This justification is not simply based on the fact that the crime is committed on the high seas, ${ }^{122}$ though that was certainly an important aspect. ${ }^{123}$ Nor is it based on the notion that the crimes associated with piracy were committed outside the territorial reach of all nations because the crimes in question were in fact committed on

122. Implementing Sosa, supra note 100, at 151 (noting that murder on the high seas was not originally subject to universal jurisdiction); see also United States v. Furlong, 18 U.S. (5 Wheat.) 184, 197-99 (1820).

123. See, e.g., Anthony Sammons, The "Under-Theorization" of Universal Jurisdiction: Implications for Legitimacy on Trials of War Criminals by National Courts, 21 BERKELEY J. INT'L L. 111, 126 (2003) (suggesting that the actual rationale for universal jurisdiction, as it arose in the context of piracy, was that pirates, "[ $\mathrm{t}] \mathrm{h}$ hrough their utilization of international waters, ... operated beyond the territorial reach of any single nation. For this reason, nations predicated their formulation of universal jurisdiction over piracy on the notion that the crime usually was committed in terra nullius, such as on the high seas where no nation exercised territorial control."); see also Becker, supra note 89 . 
ships, which have long been recognized as territorial extensions of the state of their flag of registration. ${ }^{124}$

Rather, the justification was even more practical. The pressures caused by the widespread nature of the crime of piracy, its warlike characteristics, the ease with which pirates could escape detection, and the high cost of maintaining a naval force large enough to fight foreign foes and pirates created the elements of necessity and urgency that lead to universal jurisdiction over the crime. ${ }^{125}$

Under this rationale, the implications of a high seas requirement for facilitators are clear. There is no reason to believe that those who facilitate piracy from within the territorial jurisdiction of a state are any more or less likely to escape detection than any other criminal within that state's boarders. Land-based facilitators neither engage in war-like tactics nor seek to evade navies at sea. From a law enforcement perspective, a landbased pirate facilitator is no different from an individual facilitating common armed robbery. If this practical rationale is accepted, the policies underlying universal jurisdiction over piracy would not be served by prosecuting territorial facilitators under the theory of universal jurisdiction.

\section{Lack of Implications on Sovereignty -In Favor of a High Seas Requirement}

A state's criminal jurisdiction under international law is largely coincident to that state's sovereignty. ${ }^{126}$ Consequently, the least controversial form of jurisdiction is over that which occurs within a

124. Implementing Sosa, supra note 100, at 151; see also S.S. "Lotus," supra note 21 at 7, 9, 22; OSCAR SCHACHTER, INTERNATIONAL LAW IN THEORY AND PRACTICE 250$52(1991)$

125. Implementing Sosa, supra note 100, at 152 ("The real problem was not the formal jurisdictional status of the high seas but the practical problem of enforcement. ... The high cost of maintaining a navy, and the need to employ it against foreign fleets, made piracy perhaps the most expensive of crimes to police. Because of the vastness of seas, pirates could easily commit their crimes undetected."); Abi-Saab, supra note 109, at 600 (noting the "elements of necessity and urgency" created by "warlike act[s] by highly mobile agents over the immensity of the high seas").

126. Piracy Analogy, supra note 98, at 188 ("International law regards criminal jurisdiction as a prerogative of sovereign states. As a result, the traditional limits on national criminal jurisdiction are largely coextensive with the limits of national sovereignty."). 
state's territorial limits. ${ }^{127}$ Additionally, states can assert jurisdiction over acts committed by or against its nationals; some states have asserted the protective principle of jurisdiction, wherein they may adjudicate acts committed abroad by and against foreign nationals, but that nonetheless affect certain important interests of the adjudicating state. ${ }^{128}$ In addition to these more traditional bases for jurisdiction, universal jurisdiction exists over certain specific and narrowly defined crimes. For the first 300 years of the Westphalian system of international law, this form of jurisdiction was reserved exclusively for piracy committed on the high seas. ${ }^{129}$

With these fundamental principles in mind, the final potential policy rationale for universal jurisdiction over piracy is that such jurisdiction does not offend the traditional notions of state sovereignty precisely because the acts at issue occur on the high seas. ${ }^{130}$ If this rationale were found to be most persuasive, there can be no question that a high seas requirement for facilitators exists. Absent such a requirement, the contemporary international law of maritime piracy would violate all notions of sovereignty contained in the original justification for the establishment of universal jurisdiction over the crime.

There is no shortage of support for the proposition that universal jurisdiction is fundamentally different from other types of jurisdiction because, "[u]nlike all other forms of international jurisdiction, the universal kind is not premised on notions of sovereignty or state consent.

127. Ian Brownlie, Principles of Public International Law 303 (5th ed. 1998) ("The principle that the courts of the place where the crime is committed may exercise jurisdiction has received universal recognition, and is but a single application of the essential territoriality of the sovereignty, the sum of legal competences, which a state has.").

128. See Implementing Sosa, supra note 100, at $124 \mathrm{n} .59$ (describing the bases for jurisdiction under international law and noting that " $[\mathrm{t}]$ he scope of the protective principle is uncertain and controversial, because under loose notions of harm and causation it could encompass a wide variety of extraterritorial conduct"); United States v. Yousef, 327 F.3d 56, 110-11 (2d Cir. 2003) ("The protective (or 'security') principle permits a State to assume jurisdiction over non-nationals for acts done abroad that affect the security of the State.") (citations omitted).

129. Eugene Kontorovich, "A Guantánamo on the Sea”: The Difficulty of Prosecuting Pirates and Terrorists, 98 CAL. L. REV. 243, 244 (2010).

130. See, e.g., Hannah ARendt, Eichmann in Jerusalem: A Report on the BANALITY OF EvIL 262 (rev. ed. 1965) (1963) (noting the pirate fell under universal jurisdiction because "he has chosen to put himself outside all organized communities" and he "acknowledg[ed] obedience to no flag whatsoever"); see also 4 WiLliam Blackstone, COMMENTARIES ON THE LAWS OF ENGLAND 71 (1979) (explaining that pirates were universally punishable because they "renounced all the benefits of society and government"). 
Rather, it is intended to override them." ${ }^{131}$ As a result of its unique nature, universal jurisdiction has traditionally been applied quite sparingly for fear that excessive application might strain diplomatic relations between states. ${ }^{132}$ Indeed, the practical consideration of interstate relations formed the basis for two first principles of international law: the principles of sovereign equality and noninterference. ${ }^{133}$ At the time when universal jurisdiction was originally granted solely to prosecute pirates, the general rule was: "no nation could have jurisdiction outside its sovereign domain except with the consent of another nation." 134

From this perspective, whether a perpetrator of piracy was physically present on the high seas at the time of the piratical act was of the utmost importance. Only if a pirate renounced sovereign protection by operating on the high seas, outside of the privateering licensing scheme, could he be subject to universal jurisdiction. ${ }^{135}$ This view can be seen in the writings of William Blackstone and Henry Kissinger alike. ${ }^{136}$ In fact,

131. Piracy Analogy, supra note 98, at 184; see also Schooner Exchange v. McFaddon, 11 U.S. (7 Cranch) 116, 136-37 (1812) ("The jurisdiction of the nation within its own territory is necessarily exclusive and absolute. It is susceptible of no limitation not imposed by itself. Any restriction upon it, deriving validity from an external source, would imply a diminution of its sovereignty to the extent of the restriction, and an investment of that sovereignty to the same extent in that power which could impose such restriction."); Nicolaos Strapatsas, Universal Jurisdiction and the International Criminal Court, 29 MANITOBA L.J. 1, 6 (2002) (observing that universal jurisdiction can threaten international relations "because [assertions of universal jurisdiction] could be interpreted by the State where the crime has been committed as . . a violation of its sovereignty"); Eugene Kontorovich, The "Define and Punish" Clause and the Limits of Universal Jurisdiction, 103 Nw. U. L. REV. 149, 168 (2009) ("By granting Congress the Define and Punish power, the Framers sought to provide a uniform standard of conduct on federal vessels and to ensure that the national government could deal with crimes that could embroil the country in disputes with foreign powers.") [hereinafter Limits of Universal Jurisdiction].

132. Implementing Sosa, supra note 100, at 125 ("Assertions of [universal jurisdiction] by one nation can be perceived as interference in the internal affairs of other countries. This can strain diplomatic relations and lead to interstate conflict.").

133. LuC REYDAMS, UNIVERSAL JURISDICTION: INTERNATIONAL AND MuNICIPAL Legal PeRsPeCtives 27 (2003) ("Currently there is no global convention with respect to criminal jurisdiction. International law leaves States a wide measure of discretion in the matter, yet postulates the existence of limits. One of them is the noninterference principle, a corollary of the sovereign equality of States.").

134. Limits of Universal Jurisdiction, supra note 131, at 172.

135. See Implementing Sosa, supra note 100, at 151 ("Pirates rejected their home states' licensing schemes, thus refusing their home states' protection.").

136. See BlaCKSTONE, supra note 130; see also Kissinger, supra note 99, at 87 ("The very concept of universal jurisdiction is of recent vintage. The sixth edition of 
UNCLOS allows states to strip pirate ships of their national character, further reflecting the concern surrounding issues of state sovereignty as it relates to universal jurisdiction over pirates. ${ }^{137}$

If one accepts the premise that the principles of state sovereignty and noninterference are fundamental to international law, and that the exercise of universal jurisdiction profoundly offends those principles, it should follow that acts committed wholly within a state's jurisdiction should be treated differently than those committed outside the territorial jurisdiction of any state. The former should be exempt from judgment by a state with no connection to the act while the latter could withstand a lesser nexus under certain circumstances. If those who first asserted universal jurisdiction over piracy understood international jurisdiction as such, it is extremely unlikely that they intended to subject to universal jurisdiction a facilitator of piracy who operated wholly within the territorial jurisdiction of another state.

\section{ThE PRACTICAL IMPACT OF THE High SEAS REQUIREMENT ON FACILITATORS}

On the surface, it may appear that a high seas requirement for facilitators of piracy jure gentium would result in impunity for the financiers of modern maritime piracy off the coast of Somalia. The casual observer might argue that, by eliminating universal jurisdiction as a potential basis to bring a land-based facilitator to court, a high seas requirement would cut off an important avenue to end impunity that would otherwise have been available and widely used to combat piracy. As will be demonstrated below, political economic theory suggests, and state practice shows, that true universal jurisdiction prosecutions of alleged pirates are exceedingly rare. In other words, a high seas requirement for facilitators would have few implications on impunity for pirate kingpins.

This section first looks at a state's decision whether to pursue a universal jurisdiction piracy prosecution through the lens of political economic theory and concludes that it is rarely in a state's interest to undertake such a prosecution. This theoretical analysis leads to two testable hypotheses: first, universal jurisdiction prosecutions should represent an extreme minority of the outcomes facing a suspected pirate; second, the overall

Black's Law Dictionary, published in 1990, does not contain even an entry for the term. The closest analogous concept listed is hostes humani generis ('enemies of the human race'). Until recently, the latter term has been applied to pirates, hijackers, and similar outlaws whose crimes were typically committed outside the territory of any state.").

137. UNCLOS, supra note 33, art. 104 ("A ship or aircraft may retain its nationality although it has become a pirate ship or aircraft. The retention or loss of nationality is determined by the law of the State from which such nationality was derived."). 
clearance rate ${ }^{138}$ for maritime piracy should be lower than that for other crimes. The section concludes by surveying relevant state practice and finding the hypotheses posed to be largely accurate.

\section{A. In Theory, Universal Jurisdiction Piracy Prosecutions Should be Exceedingly Rare}

For the purposes of this section, let us assume that states act in accordance with the modern version of the rational choice model of states. The rational choice model explains why states are unitary, rational actors in pursuit of their own interests on the world stage. ${ }^{139}$ Unlike the realist camp, which argues that states pursue only short-term plans to increase power relative to other states, the modern version allows for more breadth in a state's conceptualization of its own interests. ${ }^{140}$ Once shunned by international lawyers, the rational choice model analysis is becoming more widely accepted, and the marketplace is now viewed as one of the most useful analogies for international relations. ${ }^{141}$ This type of political economic analysis suggests that market forces discourage universal jurisdiction piracy prosecutions. This is true whether such prosecutions are viewed as a commons problem or as a public goods problem. This section will consider both potential framings in turn.

\section{Universal Jurisdiction Prosecutions as a Commons Problem}

A 1968 essay by Garrett Hardin described the lamentable situation of a large group of herders sharing common grazing land. ${ }^{142}$ Each herder enjoyed the full benefit of adding an additional cow to the pasture but only suffered a fraction of the cost of that additional cow because all the herders shared the degradation of the grazing land. ${ }^{143}$ Assuming all of the herders were rational beings, an over-grazed and un-productive pasture was an economic inevitability. ${ }^{144}$ Hardin's solution was to privatize the

138. The clearance rate is the ratio of offenders sent for prosecution to the total number of known offenders.

139. Kenneth W. Abbott, Modern International Relations Theory: A Prospectus for International Lawyers, 14 YALE J. INT'L L. 335, 349-51 (1989).

140. Id. at 351 .

141. See id. at 375.

142. Garrett Hardin, The Tragedy of the Commons, 162 SCIENCE 1243, 1244 (1968).

143. Id.

144. See id. 
common property and compel each herder to both enjoy the full benefit and pay the full cost of his actions. ${ }^{145}$ This solution, dubbed "mutual coercion, mutually agreed upon," led to the economically and socially optimal result. ${ }^{146}$

Hardin's Tragedy of the Commons is thus fundamentally a story about internalizing externalities. Externalities arise whenever the conduct of a market actor unintentionally affects the circumstances of another market actor; they come in two forms: positive and negative. ${ }^{147}$ Negative externalities, like the land degradation described in Hardin's essay, occur when a market participant acts in a way that is detrimental to another participant. ${ }^{148}$ Positive externalities, conversely, arise when a market participant acts in a way that benefits other participants. ${ }^{149}$ In either case, a community where externalities are present will benefit by internalizing those externalities, which will in turn lead to participants engaging in the externality-causing activity at more nearly optimal levels. ${ }^{150}$ Indeed, Coase famously argued that if certain conditions are met, market participants will naturally work towards internalizing externalities over time. ${ }^{151}$

Just as one herder adding an additional cow to the common pasture creates a negative externality, universal jurisdiction prosecutions of pirates create a positive externality. The prosecuting state bears all the cost of a complex prosecution, while the entire community of nations benefits from the deterrent effect of that prosecution on future pirates. And to be sure, universal jurisdiction prosecutions, of pirates and nonpirates alike, are both politically and economically costly for the prosecuting state. ${ }^{152}$ Just as herders with unaccounted-for negative externalities will perform too much of a damaging activity, states with unaccounted-for positive externalities will perform too little of a beneficial activity.

145. Id. at 1247.

146. Id.

147. Abbott, supra note 139, at 388-89; William H. Riker \& Peter C. OrdeshoOK, An InTROdUCtion to Positive POLITICAL THEORY 256 (1973).

148. Abbot, supra note 128, at 388-89; RIKER \& ORDESHOOK, supra note 136, at $257-58$.

149. Abbot, supra note 128, at 389; RIKER \& ORDESHOOK, supra note 136, at 258.

150. Abbott, supra note 139 , at 390.

151. See generally R.H. Coase, The Problem of Social Cost, 3 J.L. AND Econ. 1 (1960).

152. Evidentiary Theory, supra note 118 , at 15 (noting that wealthy states pursue universal jurisdiction prosecutions in a way that minimizes political and economic cost); REYDAMS, supra note 133, at 222 (observing that universal jurisdiction prosecutions are a luxury that only wealthy nations can afford); Garry J. Bass, The Adolf Eichmann Case: Universal and National Jurisdiction, in UnIVERSAL JURISDICTION: NATIONAL COURTS and the Prosecution of Serious Crimes under InTERnational LaW 77, 78 (Stephen Macedo ed., 2004) (noting the possibility that a universal jurisdiction prosecution could lead to diplomatic difficulties with other nations). 
Piracy cases prosecuted by a state with a more traditional jurisdictional basis are more successful at internalizing externalities than universal jurisdiction prosecutions. Through prosecutions under the territorial, nationality, or protective principles of jurisdiction, the prosecuting state can further secure its territory, vindicate the rights of its nationals, demonstrate to the international community its responsibility over its nationals, or protect an important state interest. The prosecuting state still bears the entire cost of the prosecution, but it enjoys more of the resulting benefits, namely that which flows from the interests territorial, national, or protective jurisdiction are meant to advance. Under this formulation, both Hardin and Coase would predict that very few states would pursue universal jurisdiction piracy prosecutions.

\section{Universal Jurisdiction Prosecutions as a Public Goods Problem}

In addition to thinking about universal jurisdiction prosecutions in terms of commons problems and externalities, one can also think of them in terms of public goods and free riders to reach the same conclusion that universal jurisdiction prosecutions should be quite rare. Upon accepting the premise that universal jurisdiction prosecutions are public goods and that states are rational actors, economic theory inevitably leads to the conclusion that market pressures will force a decrease in the rate of such prosecutions. ${ }^{153}$

Public goods have the two identifying characteristics of "jointness" and "non-excludability." 154 By jointness, economists mean that consumption of a good by one user does not reduce the availability of that good for other users. ${ }^{155}$ Non-excludability means that all participants can enjoy the benefit of a good, regardless of whether that user takes part in producing it. ${ }^{156} \mathrm{In}$

153. See Jeffrey L. Dunoff \& Joel P. Trachtman, Economic Analysis of International Law, 24 YALE J. INT'L L. 1, 16 (1999) (noting that, to the extent that something is a public good, theorists expect them to be under-produced by a market acting alone); see also RAYMOND G. BATINA \& TOSHIHIRO IHORI, Public GoOds: THEORIES AND EVIDENCE 15 (2005) (describing the conditions leading to the underproduction of public goods).

154. Abbott, supra note 139, at 377; John A. C. Conybeare, Public Goods, Prisoners' Dilemmas and the International Political Economy, 28 INT'L STUD. Q. 5, 6 (1984); see also William J. Baumol \& Alan S. Blinder, ECONOMICS: Principles AND POlicy 31415 (10th ed. 2006); RIKER \& ORDESHOOK, supra note 147, at 247, 259-64.

155. Abbott, supra note 128 , at 377.

156. Id. 
the case of a pure public good, "the marginal cost of providing another agent with the good is zero, and ... no one can be excluded from enjoying its benefits." 157 Put another way, a pure public good is consumed equally by all market participants, regardless of whether any given participant actually contributed to the production of the good in question.

Universal jurisdiction piracy prosecutions, or perhaps more accurately, the benefits that flow from universal jurisdiction piracy prosecutions, appear to be a prime example of a public good. By definition, universal jurisdiction prosecutions are performed by states with no territorial, national, or protective connection to the piratical act or acts at issue. ${ }^{158}$ Thus, the core benefits of a universal jurisdiction prosecution, from the perspective of the state conducting the prosecution, are limited to the deterrent effect of that prosecution on future would-be pirates and the increased stability on the high seas resulting from that deterrence. ${ }^{159}$

This deterrent effect, even if modest, is enjoyed by all nations who engage in or benefit from maritime transport, regardless of whether that nation participates in conducting universal jurisdiction piracy prosecutions. The benefits flow automatically from the mere existence of the prosecution, and no additional expense is required for the non-prosecuting state to share in those benefits. Although it is not the case that all nations share in

157. BATINA \& IHORI, supra note 153 , at 2 .

158. PRINCETON PRINCIPLES, supra note 87, at 28.

159. The prosecuting state has the additional benefit of improved standing within the international community for performing its duty to cooperate in the repression of piracy as articulated in UNCLOS art. 101. This benefit is not a public good, but states tend to cite the deterrence rationale more frequently than the duty rationale, although commentators often discuss both simultaneously. Additionally, the duty rationale does not represent the unanimous position of scholars. See, e.g., Agence France-Presse, UN calls for tougher prosecution of pirates, THE RAW STORY (Nov. 19, 2012, 7:55 PM), http://www.rawstory.com/rs/2012/11/19/un-calls-for-tougher-prosecution-of-pirates/ ("The United Nations on Monday called for stronger prosecutions of pirates and more action by shipping companies to deter bandits at sea."); Thomas Kelly, U.S. Dep't of State's Principal Deputy Assistant Sec'y, Bureau of Political-Military Affairs, Remarks at Combating Piracy Week: The U.S. Government's Approach to Countering Somali Piracy (Oct. 25, 2012), available at http://www.state.gov/t/pm/rls/rm/199929.htm ("Now let me turn to another aspect of our response - our efforts to deter piracy through effective apprehension, prosecution, and incarceration of pirates and their supporters and financiers. . . Prosecutions is one key to deterrence, but this must include the prosecution of the masterminds and funders along with the gunmen."); but see Elizabeth Andersen et. al., Suppressing Maritime Piracy: Exploring Options in International Law 9 (One Earth Future Found., Academic Council on the U.N. Sys., \& Am. Soc'y of Int'l Law, Workshop Report) ("Some commentators read these and other provisions as creating a duty for states, which many are neglecting. Kenya, by this interpretation, would be seen as fulfilling its affirmative duty by prosecuting pirates on its soil. Other commentators reject this interpretation, arguing that the concept of universal jurisdiction permits, but does not require, states to prosecute maritime pirates."). 
the benefits equally, since those more intimately or frequently involved in maritime transport accrue a marginally greater benefit from piracy's repression than states whose connection is more tenuous, it is highly likely that all nations share in the benefit to some extent. ${ }^{160}$ Thus it is reasonable to conclude that the benefits flowing from a universal jurisdiction piracy prosecution have nearly all the characteristics of a public good.

Once it can be established that something has the characteristics of a public good, it is almost axiomatic that the good will be under-produced in a functioning market. ${ }^{161}$ This under-production is a result of the wellknown problem of free-riding, where entities who incur no costs in creating a public good nonetheless obtain the full benefit of that good. ${ }^{162}$ Much has been made of what must be done to counteract the public good/free-rider problem and ensure public goods are produced at a socially optimal level. The most famous of these approaches is Samuelson's "first-best" provision of pure public goods, ${ }^{163}$ which states, "[a]t the firstbest social optimum the public good should be supplied so that the sum of the willingness-to-pay (WTP) for those who benefit from the good is

160. This is because piracy has a generalized impact on the cost of trade, and almost all of the world's goods are transported at sea. Sami Bensassi \& Inmaculada Martínez-Zarzoso, How Costly is Modern Maritime Piracy for the International Community?, 20 REV. INT'L ECON 869, 870 (2012), available at http://onlinelibrary.wiley.com/doi/ $10.1111 /$ roie. $12000 /$ pdf (finding that maritime piracy cost the international community $\$ 24.5$ billion in terms of trade destruction in 2012); Int'l Mar. Org., IMO's contribution to sustainable maritime development 3 (IMO Brochure), http://www.imo.org/ourwork/ technicalcooperation/documents/brochure/english.pdf (noting that $90 \%$ of the world's trade is carried at sea).

161. Dunoff \& Trachtman, supra note 153, at 16; see BATINA \& IHORI, supra note 153 , at 15 .

162. See Abbott, supra note 139, at 378 (“'[B] ecause of free-riding, [collective goods] are typically supplied at less than optimal levels, if at all."); Tim Besley, Thiemo Fetzer \& Hannes Mueller, One Kind of Lawlessness: Estimating the Welfare Cost of Somali Piracy 4 (Int'l Growth Ctr., working paper, Apr. 20, 2012), available at http://www.theigc.org/ publications/working-paper/piracy-somalia-costs-billions ("One of the central difficulties in combatting predation due to piracy is the need for international cooperation. There is a classic public good problem with the usual potential for free-riding.").

163. See Paul A. Samuelson, The Pure Theory of Public Expenditure, 36 REV. ECon. \& StAT. 387, 387-89 (1954); Paul A. Samuelson, Diagrammatic Exposition of a Theory of Public Expenditure, 37 Rev. Econ. \& STAT. 350, 350-56 (1955); Paul A. Samuelson, Aspects of Public Expenditure Theories, 40 REv. Econ. \& STAT. 332, 332 38 (1958); Paul A. Samuelson, Pure Theory of Public Expenditures and Taxation, in Public Economics: An Analysis of Public Production and Consumption AND their Relations to the Private Sectors (J. Margolis \& H. Guitton eds., 1969). 
equal to the marginal production cost." ${ }^{164}$ In other words, states should pay for the public good proportionately to its perceived benefit from that public good.

Such a mechanism is much easier to describe than to implement, and although various attempts have been advanced to achieve socially optimal results for public goods problems, ${ }^{165}$ the issue remains a vexing one. ${ }^{166}$ Fortunately, in the specific case of universal jurisdiction piracy prosecutions, the public good exists alongside a more privatized substitute: piracy prosecutions under a traditional theory of jurisdiction. With a universal jurisdiction prosecution, the benefit to the prosecuting state comes in the form of deterrence, a benefit which flows to the international community as a whole. On the other hand, a more traditional prosecution produces additional benefit(s) for the state of securing its territory, vindicating the rights of its nationals, demonstrating responsibility over its nationals to the international community, or protecting an important state interest. Therefore, traditional piracy prosecutions look significantly less like a public good than their universal jurisdiction counterparts and are more likely to be produced in a market.

Consequently, if one assumes states enter into a cost-benefit analysis when deciding whether to engage in complex international prosecutions, cases brought under traditional theories of international jurisdiction should be more common than those brought under the theory of universal jurisdiction. In both instances, traditional and universal jurisdiction piracy prosecutions, the economic cost of a prosecution is relatively high. ${ }^{167}$ Yet there are political costs associated with universal jurisdiction prosecutions that are less present in more traditional cases. ${ }^{168}$ These political costs come

164. BATINA \& IHORI, supra note 153 , at 9.

165. E.g., Erik Lindahl, Just Taxation-A Positive Solution, in Classics IN THE Theory of PUBlic FinANCe 168 (Richard A. Musgrave \& Alan T. Peacock eds., Elizabeth Henderson, trans., 1958) (1919).

166. See BATINA \& IHORI, supra note 153, at 1 ("[O]ne of the biggest problems [in welfare economics] is that there is a class of goods that provides utility or improves the efficiency of production, but which the private sector has great difficulty providing, public goods.").

167. Eugene Kontorovich, "A Guantánamo on the Sea”: The Difficulty of Prosecuting Pirates and Terrorists, 98 CALIF. L. REV. 243, 245, 262-66 (2010) (describing the difficulties inherent in piracy prosecutions, including establishing and proving who is a pirate, preserving evidence obtained on the high seas, and providing adequate counsel and translation services).

168. Evidentiary Theory, supra note 118 ("The exercise of universal jurisdiction is politically costly for a state. It means embroiling one's diplomatic apparatus in an imbroglio, and, quite likely, a confrontation with one or more states ... it means burdening one's court system with what will probably be an incredibly complex and problematic case; and it almost certainly means a great deal of domestic turmoil and controversy. Why would a country bother?"); see also Michael Kirby, Universal Jurisdiction and Judicial 
in the form of potential friction between states, overly burdened domestic dockets, and a frustrated public. ${ }^{169}$ Moreover, while costs are traditionally borne by the prosecuting state, virtually all of the benefits of a universal jurisdiction prosecution flow instead to the international community. ${ }^{170}$ Under traditional jurisdictional theories, more benefits flow directly to the prosecuting state. This is true whether one speaks in terms of internalizing externalities arising out of a commons problem or privatizing public goods to avoid a free-rider problem.

\section{B. State Practice Shows Universal Jurisdiction Piracy Prosecutions Are Rare}

The above economic analysis leads to two related hypotheses. First, for all the reasons stated above, universal jurisdiction piracy prosecution should represent a small minority of all outcomes that befall a suspected pirate. Second, as a more general matter, high seas piracies should be prosecuted at a lower rate than similar domestic crimes. This is because, even if costs are minimized and internalized to the greatest extent feasible, the cost of any given piracy prosecution will be higher than an inherently simpler prosecution of, for example, a domestic bank robber. This is due to practical difficulties inherent in piracy prosecution but rare in domestic armed robbery trials, including evidence preservation, provision of counsel and translation services, and prisoner transfer and repatriation issues. Moreover, even if a state with a traditional jurisdictional nexus engages in a piracy prosecution, such engagement does not negate the deterrent benefits that flow to the international community. This leaves behind two market forces, positive externalities and characteristics of a public good, that will continue to drive down the

Reluctance: A New "Fourteen Points", in Universal Jurisdiction: National COURTS AND the Prosecution of Serious Crimes under International Law 240, 256 (Stephen Macedo ed., 2004) (noting that domestic judges, especially those with heavy caseloads, are likely to resent universal jurisdiction prosecutions).

169. See Evidentiary Theory, supra note 118; Kirby, supra note 168; see also Beate Lakotta, An Expensive Farce: Germany's Somali Pirate Trial Is Pointless, SPIEGEl Online INTERNATIONAL (Sept. 12, 2012, 10:24 AM), http://www.spiegel.de/international/germany/ German-trial-of-somali-pirates-turns-into-pointless-and-expensive-farce-a-855252.html (expressing frustration over a Somali piracy trial in Germany).

170. In recent years, the international community has worked out a "cost-sharing" mechanism for regional universal jurisdiction prosecutions. This mechanism will be discussed in Part IV(B), infra. 
rate of piracy prosecutions. This section tests the two above hypotheses against the available empirical evidence and finds that both have held true historically and in the modern context.

\section{Universal Jurisdiction Piracy Prosecutions Are a Minority Outcome}

Empirical evidence suggests universal jurisdiction prosecutions have represented, and continue to represent, a small minority of all piracy outcomes. For example, Alfred P. Rubin in 1998 surveyed piracy prosecutions over the past three hundred years and found fewer than five universal jurisdiction prosecutions. ${ }^{171}$ Though this figure does not include unreported universal jurisdiction prosecutions that took place in remote regions, with only five enumerated trials, universal jurisdiction prosecutions almost certainly represented a vanishingly small proportion of all piracy outcomes between 1698 and $1998 .{ }^{172}$ It is also worth noting that as early as 1867 , universal jurisdiction piracy prosecutions were being thought of in terms of internalized costs and externalized benefits:

Besides [England is] not the only Power with large interests at stake. French, Americans, and Germans carry on an extensive trade ... Why should we then incur singly the expense of suppressing piracy if each provided a couple of gunboats the force would suffice for the safety foreign shipping which is all that devolves upon ... . why should the English tax payer alone bear the expense?173

Eugene Kontorovich and Steven Art picked up where Rubin left off and conducted an empirical study of piracy prosecutions from 1998 to 2009, which includes the first few years of the resurgence of Somali piracy. ${ }^{174}$ They found only seventeen universal jurisdiction piracy prosecutions out of the 1158 reported attacks. ${ }^{175}$ Broken down further, Kontorovich and Art found a universal jurisdiction prosecution rate of $0.53 \%$ for the years 1998 to 2007 and universal jurisdiction prosecution rate of $3.22 \%$ for the years 2008 and $2009 .{ }^{176}$

State practice from 2008 to 2012 shows that the international community has taken steps to minimize the cost of universal jurisdiction prosecutions

171. See Alfred P. Rubin, The Law of Piracy 346-47 n.13, 348 n.50 (2d ed. 1998); see also Piracy Analogy, supra note 88, at 192 ("[V]ery few criminal prosecutions for piracy can be found that depended on the universal principle.").

172. See id.

173. Besley et. al., supra note 162, at 4 (quoting The London and China Telegraph from Feb. 4, 1867) (alteration in original).

174. Eugene Kontorovich \& Steven Art, An Empirical Examination of Universal Jurisdiction for Piracy, 104 AM. SoC'Y INT'L L. 436, 436 (2010), available at www.asil. org/ajil/July2010selectedpiece.pdf [hereinafter Empirical Examination].

175. Id. at 444 .

176. Id. at 445 . 
and has recognized a commons/public goods problem that is inherent in such prosecutions. ${ }^{177}$ By pursuing a strategy that directs prosecutions towards regional nations and funds them largely through United Nations mechanisms, the international community is both minimizing the cost of piracy prosecutions and spreading that cost more equitably among the nations most directly benefitting from the prosecutions. Nonetheless, a universal jurisdiction prosecution remains a low-probability outcome for a captured pirate. A traditional universal jurisdiction prosecution would result from the capturing state conducting the prosecution of a pirate captured on the high seas. ${ }^{178}$ However, capturing states choose to simply release captured pirates eighty to ninety percent of the time. ${ }^{179}$ In response

177. See, e.g., EU Naval Force Transfers Twelve Suspect Pirates to Mauritius for Prosecution After Attack on Merchant Vessel off Somalia, EU NAVFOR SomAlia (Jan. 25, 2013, 3:23 PM), http://eunavfor.eu/eu-naval-force-transfers-twelve-suspect-piratesto-mauritius-for-prosecution-after-attack-on-merchant-vessel-off-somalia-2/ (noting the prisoner transfer agreement between the European Union and Mauritius); Support to the Trial and Related Treatment of Piracy Suspects, COUNTER-PIRACY Programme Issue 6 (U.N. Office on Drugs \& Crime), June 2011, available at http://www.unodc.org/documents/ Piracy/UNODC_Brochure_Issue_6_WV.pdf (describing the UNODC's capacity building efforts); Support to the Trial and Related Treatment of Piracy Suspects, COUNTER-PIRACY Programme Issue 7 (U.N. Office on Drugs \& Crime), Sept./Oct. 2011, at 1, available at http://www.unodc.org/documents/Piracy/UNODC_Brochure_Issue_7_WV.pdf (identifying the Piracy Prisoner Transfer Programme).

178. UNCLOS, supra note 33, art. 105 ("On the high seas, or in any other place outside the jurisdiction of any State, every State may seize a pirate ship or aircraft, or a ship or aircraft taken by piracy and under the control of pirates, and arrest the persons and seize the property on board. The courts of the State which carried out the seizure may decide upon the penalties to be imposed, and may also determine the action to be taken with regard to the ships, aircraft or property, subject to the rights of third parties acting in good faith.") (emphasis added).

179. See Empirical Examination, supra note 174, at 450 (noting that anti-piracy patrols continue to release most of the captured suspects); Brian Brady, Navy frees four out of five suspected Somali pirates, THE INDEPENDENT (Apr. 8, 2012), http://www. independent.co.uk/news/world/africa/navy-frees-four-out-of-five-suspected-somali-pirates7626977.html (citing official UK Ministry of Defence numbers that 28 of the 34 ships boarded in 2008 were released and that 229 of the 279 pirates detained were released); First Italian Judgment in a piracy Case: Public Prosecutor of Rome Condemns Four Somali Pirates, OCEANUS Live (Oct. 31, 2012, 1:48 PM), http://www.ocean uslive.org/main/viewnews.aspx?uid=00000545 ("Italy had adopted in the past against pirates the technique of 'catch and release', ie [sic] delivering pirates to the states to which they belong. This technique has been criticized by the UN Security Council because it was considered an incentive problem."); US Planning, Maritime SECURITY REVIEW (Mar. 17, 2011), http://www.marsecreview.com/2011/03/us-planning/ ("The prosecution of pirates is difficult. Jurisdiction is tricky, and stakeholder countries are often unwilling or unable to put them through their court systems. Out of an estimated 800 who have 
to this elevated "catch and release" rate, nations conducting naval patrols have signed transfer agreements with regional nations including Kenya, Seychelles, Tanzania, and Mauritius, whereby the capturing state transfers the pirates to a regional nation to undergo a universal jurisdiction prosecution financed and supported by the United Nations and the governments of other states. ${ }^{180}$ This approach recognizes and seeks to ameliorate the market forces described above by moving toward a situation where states' financial contributions to piracy prosecutions are proportionate to the benefits accrued through those prosecutions. Nonetheless, despite the concerted effort to increase the rate of universal jurisdiction prosecutions to date, such prosecutions remain a relatively rare occurrence.

\section{Maritime Piracy is Prosecuted at a Lower Rate than Other Crimes}

Apart from predicting that a universal jurisdiction prosecution would be a rare outcome for a suspected pirate, the political economic theory discussed above would also predict the overall rate of piracy prosecutions to be lower than that of domestic offenses. Because prosecution rates are not generally reported by states, clearance rates are used as a proxy for prosecution rates. ${ }^{181}$ A crime is "cleared" when a suspect is arrested and referred for prosecution. ${ }^{182}$ The clearance rate is thus the ratio of those referred for prosecution to the total number of known offenders.

In the United States, the clearance rate for all violent crimes is roughly forty-five percent, and twenty-seven percent for robbery. ${ }^{183}$ In the European Union, the clearance rates are even higher, with a clearance rate of seventy

been turned over for prosecution, no witness could say how many had actually been prosecuted when grilled by Larsen. The closest they got to an answer was 'very few."').

180. E.g., Judicial international cooperation to end impunity, EUR. UNION EUROPEAN EXTERNAL ACTION SERVICE, http://eeas.europa.eu/piracy/judicial_cooperation_en.htm ("The EU has therefore signed transfer agreements with countries in the region- $\overline{\text { the Seychelles }}$ (2009), Mauritius (2011) - and is negotiating another one with Tanzania. At the moment, transfers to Kenya are possible on a case by case basis. The judicial systems of these countries were not fully prepared to cope with the additional complexities and workload of transferred piracy suspects. A joint EU/UNODC programme of support for the justice system in Kenya was launched in May 2009 to provide Kenya with practical assistance to cope with the extra demands associated with the prosecution and detention of piracy suspects ( $€ 1.75$ million). Similar support programmes are available to the Seychelles ( $€ 0.78$ million) and Mauritius ( $€ 1.08$ million). The EU and its Member States are thus the largest contributor to the UNODC counter-piracy programme.").

181. Empirical Examination, supra note 174, at 446.

182. Id. n.43.

183. Fed. Bureau of Investigation, U.S. Dep'T of Justice, 2008 Crime in the United States: Percent of Offenses Cleared by Arrest or Exceptional Means tbl.26, (2009), available at http://www2.fbi.gov/ucr/cius2008/data/table_26.html. 
percent for homicide and forty-one percent for robbery. ${ }^{184}$ The average clearance rate for all crime worldwide is fifty-one percent. ${ }^{185}$ Compare those percentages to the $1.47 \%$ rate at which captured pirates were sent for prosecution between 1998 and $2009 .{ }^{186}$ If anything, that $1.47 \%$ rate is on the high side since it is well documented that a substantial fraction of pirate attacks go unreported. ${ }^{187}$ At best, the clearance rate for piracy is between sixty and eighty percent lower than the global average for all crimes.

\section{CONCLUDING REMARKS}

The available evidence suggests that an inciter or intentional facilitator of maritime piracy must be physically present on the high seas to be subject to universal jurisdiction. The drafters of the 1932 Harvard Draft Convention on Piracy made it clear that incitement and intentional facilitation of piracy were included as a matter of convenience, essentially allowing for guilt by association. Rather than forcing the prosecuting state to show that each individual aboard a suspected pirate ship personally committed an act of piracy, or personally participated in operating the ship, mere presence aboard the ship would be enough to sustain a conviction. ${ }^{188}$ While it would be fair to say the reasoning employed by the Harvard Draft Convention was repeatedly endorsed throughout the next fifty years, at the very least it is clear that subsequent stewards of piracy's definition under international law never explicitly deviated from the initial conclusion that facilitators must be on the high seas to be subjected to universal jurisdiction. Any arguments to the contrary rest on a policy-favorable reading of UNCLOS and its history, mistaking pronouncements concerning piracies committed on terra nullius with those related to the creation of separate jurisdictional requirements for direct perpetrators and facilitators.

Furthermore, a high seas requirement is not likely to result in impunity for pirate kingpins who never leave dry land. From the premise that states are rational actors seeking to maximize self-defined benefits from

184. Ming-Jen Lin, Does democracy increase crime? The evidence from international data, 35 J. COMP. ECON. 467, 471 (2007) (citing Interpol figures).

185. Empirical Examination, supra note 174, at 447.

186. Id. at 444-45.

187. Pirate attacks under-reported, forum told, EDMONTON JouRnAL (Feb. 9, 2012), $\mathrm{http} / /$ /www2.canada.com/edmontonjournal/news/business/story.html?id=4ddff96f-a9ed-44 e6-9c9b-27dbca7f9f2b.

188. See Harvard Draft Convention, supra note 23, art. 3. 
operating on the world stage while minimizing the cost of doing so, it follows naturally that universal jurisdiction piracy prosecutions are not necessary to reach pirate financiers and facilitators. The costs of such prosecutions are high and relatively fixed, regardless of which state conducts the prosecution. The benefits, however, are further internalized and therefore maximized when the state conducting the prosecution has a more substantial connection to the defendant. Moreover, the international nature of global shipping, combined with multiple avenues of sovereigntybased international jurisdiction, results in a situation where even if one state with jurisdiction is unwilling or unable to prosecute, other states with traditional connections will be available to fill in the gap. For the reasons described above, states with more traditional jurisdictional nexuses are more likely to prosecute than those relying solely on universal jurisdiction.

The answer to Chief Justice Marshall's question thus remains unchanged by the two centuries that passed between United States v. Palmer and United States $v$. Ali. It cannot be believed that piracy jure gentium encompasses "the subject of a foreign prince, who, within the dominions of that prince, should advise a person, about to sail in the ship of his sovereign, to commit murder or robbery." "189 As it relates to the modern resurgence of east African piracy and the financiers and facilitators who turned that resurgence into an international criminal epidemic, that might not be such a terrible thing.

189. Palmer, supra note 1. 